Engineering Sustainability Volume 165 Issue ES1

Urban futures and the code for sustainable homes

Hunt, Lombardi, Farmani, et al.
Proceedings of the Institution of Civil Engineers Engineering Sustainability 165 March 2012 Issue ES1 Pages 37-58 http://dx.doi.org/10.1680/ensu.2012.165.1.37 Paper 1100022

Received 18/06/2011_Accepted 16/11/2011

Keywords: drainage \& irrigation/sewage treatment \& disposal/ water supply

\title{
Urban futures and the code for sustainable homes
}

Dexter V. L. Hunt MEng, PhD

Research Fellow, School of Civil Engineering, College of Engineering and Physical Sciences, University of Birmingham, Birmingham, UK

D. Rachel Lombardi PhD

Research Fellow, School of Civil Engineering, College of Engineering and Physical Sciences, University of Birmingham, Birmingham, UK

Raziyeh Farmani PhD

Senior Research Fellow, Centre for Water Systems, College of Engineering, Mathematics and Physical Sciences, University of Exeter, Exeter, UK

Ian Jefferson BEng, PhD, DIS, FGS

Senior Lecturer, School of Civil Engineering, College of Engineering and

Physical Sciences, University of Birmingham, Birmingham, UK
Fayyaz A. Memon MSc, PhD, CEng, CEnv, DIC, MCIWEM, FHEA Senior Lecturer, Centre for Water Systems, College of Engineering, Mathematics and Physical Sciences, University of Exeter, Exeter, UK David Butler MSC, PhD, DIC, CEng, CEnv, FICE, FCIWEM, FHEA Professor of Water Engineering, Centre for Water Systems, College of Engineering, Mathematics and Physical Sciences, University of Exeter, Exeter, UK

Chris D. F. Rogers Eur Ing, BSC, PhD, CEng, MICE, MIHT

Professor of Geotechnical Engineering, School of Civil Engineering, College of Engineering and Physical Sciences, University of Birmingham,

Birmingham, UK

A 6.6 ha $\left(66000 \mathrm{~m}^{2}\right)$ regeneration site, commonly referred to as Luneside East, is to be turned from a run down, economically under-achieving area of Lancaster, UK, into a new, distinctive, vibrant, sustainable quarter of the city. As a result several aspects of water planning for 350 new homes and $8000 \mathrm{~m}^{2}$ of workspace needed to be considered before any infrastructure investment was undertaken. This included assessment of the future capacity requirements (i.e. inflows and outflows) for water infrastructure (i.e. mains water supply, wastewater disposal, rainwater storage and stormwater disposal) much of which will be located underground. This paper looks at the implications of various water management strategies on the Luneside East site (e.g. water-efficient appliances, greywater recycling and rainwater harvesting) in line with current policy measures that focus on technology changes alone (e.g. the code for sustainable homes). Based on these findings this paper outlines some basic implications for technological resilience discussed in the context of four 'world views' - that is, the urban futures scenarios considered in this special issue. Conclusions are drawn as to how far this can take engineers, planners and developers in understanding and planning for resilient water infrastructure within a development like Luneside East.

\section{Introduction}

Lancaster City Council (LCC) in the UK is actively seeking to transform a run down, economically under-achieving and lifeless area of Lancaster (Figure 1) into a new, distinctive, vibrant, sustainable quarter of the city with a balanced community (LCC, 2004). Early proposals suggested turning this 6.6 ha site into a high quality living environment with approximately 350 new homes of different types and tenures and $8000 \mathrm{~m}^{2}$ of workspace, a range of leisure opportunities and new public spaces (LCC, 2004). Points for consideration with respect to water raised within the planning documents are as follows (LCC, 2004, 2007a, 2007b).

(a) Clean water mains run along St Georges Quay and Long Marsh Lane.

(b) A non-operational private water main (former Forbo linoleum mill) runs across the site.

(c) A separate metered water supply will be required at the developer's expense.

(d) On-site mains and services should be constructed from suitable materials. (e) Site drainage must be a separate system with only foul drainage connected to the foul sewer.

(f) Greywater and ground contaminants must not be discharged to public sewers.

( $g$ ) Careful consideration of the strategic flood risk assessment is needed. Location of new development should be in the lowest flood risk areas.

(h) Efficient use of water (including greywater management) and sustainable drainage system (SUDS).

In 2010, owing to a downturn in the market the development on site had not progressed past the original conceptual design, and uncertainty surrounded whether this option remained viable for the area. In December 2010, a workshop was held between LCC, the developer, local councillors, community groups and the urban futures (UF) project in order to discuss, among other things, how design decisions (point $(h)$, above) taken now in the name of sustainability might impact on current water demands and associated infrastructure requirements (e.g. stormwater outflow, wastewater outflow and the requirement for 
Engineering Sustainability

Volume 165 Issue ES1
Urban futures and the code for

sustainable homes

Hunt, Lombardi, Farmani, et al.

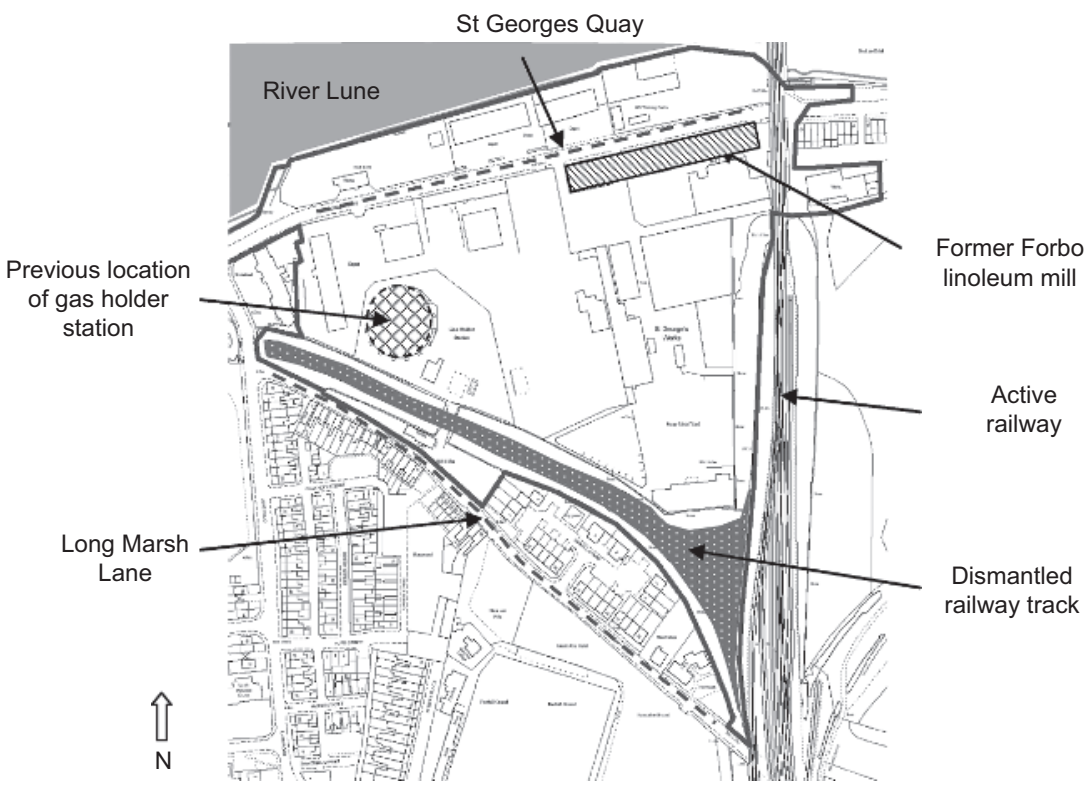

Figure 1. Plan view of the Luneside East regeneration site,

Lancaster, UK (modified from LCC, 2007a)

underground rainwater harvesting (RWH) storage tanks) within the boundaries of the site. The various water management strategies, now referred to as design cases, are discussed in Section 2. The results of a detailed water infrastructure analysis (as listed below) are presented within Section 3. These include assessing the impact of

(a) technology efficiency and potable/non-potable demands (Section 3.1)

(b) greywater recycling and associated wastewater outflow volumes (Section 3.2)

(c) RWH (from roofs) and associated stormwater outflow volumes (Section 3.3).

It should be noted that a strong emphasis on technology within this paper is because this must be included during the design stages, as opposed to retrofit, if cost-effective solutions are to be sought. While sustainable user behaviour is undoubtedly linked to the sustainable performance of items $(a)$ to $(c)$ above, these are longer-term issues that need to be addressed during the lifetime of the development (see below). By making changes to one variable (i.e. technological efficiency) while keeping others constant (i.e. user behaviour and climate) a rigorous analysis of the direct impact of technology can be found. In so doing the findings of the research can be used to highlight some of the shortfalls within a number of sustainable water management policies $(a)-(e)$ below, suggested for coming years (CLG, 2010a; Defra, 2010), in which identical assumptions and a focus on 'techno-fix' solutions have been made (a) level 1: CSH (new public and private dwellings applicable now)

(b) level 3: CSH (new public and private dwellings by 2013, already applied to social housing)

(c) level 6: CSH (new public and private dwellings by 2016)

(d) reduce water consumption by $25 \%$ (office and nonoffice estates by 2020)

(e) reduce water consumption to $3 \mathrm{~m}^{3} /$ person per year or 12 1/employee per day (new office buildings or major office refurbishments by 2020).

In this list CSH stands for the code for sustainable homes, and reductions within government estates are relative to 2004/2005 levels. Based on the analyses performed here some basic implications for localised resilience (i.e. within the confines of the Luneside East boundary) are discussed in Section 4. The limitations of the analyses in moving us towards (rather than away from) a less unsustainable future are discussed in Section 5 ; this includes the impact of user behaviour, outdoor water use and climate change. A list of generic recommendations for greywater and RWH is outlined in addition to other waterrelated recommendations for the site and a set of conclusions specific to Luneside East is then presented in Section 6.

An accompanying paper by Farmani et al. (2012) provides a water resource and infrastructure context for the broader northwest region and outlines the local water provider's (United Utilities) role, the regulatory regime and the overall future resilience implications (including user behaviour) for the 
Engineering Sustainability

Volume 165 Issue ES1
Urban futures and the code for

sustainable homes

Hunt, Lombardi, Farmani, et al. surrounding area using the UF methodology, as outlined in this special issue by Rogers et al. (2012).

\section{Water infrastructure analysis}

This section provides details of a water infrastructure analysis undertaken for Luneside East. Six design cases for water demand are proposed that are directly in line with UK policy requirements to improve technological efficiency alone (e.g. $\mathrm{CSH}$ ). A detailed account of the various assumptions being made for water demand, both at site level and per person, are discussed here; including the water demand benchmarks being adopted (Sections 2.2 and 2.3). The results of the analysis performed using these design cases are presented in Section 3.

\subsection{Urban futures scenarios and six design cases for Luneside East}

LCC is well versed at examining various future options for the development of Lancaster, shown most recently by the core strategy document that considered the year 2021 (LCC, 2004, 2007a). In the same manner UF research is about considering implications for the resilience of 'sustainability solutions' - that is, solutions that are adopted now in the name of sustainability (Boyko et al., 2012; Hunt et al., 2010a, 2010b, 2011; Hunt et al., Using scenarios to explore urban futures, in preparation). These scenarios refined for the UK urban situation are listed below:

- Market forces: The self-correcting logic of the market predominates, with individualism and materialism as core human values. Well-functioning markets are thus considered the key to resolving social, economic and environmental problems. This assumes the global system in the twenty-first century evolves without major surprise and incremental market adjustments are able to cope with social, economic and environmental problems as they arise.

- Policy reform: Government action is promoted in an attempt to reduce poverty and social conflict, although behaviour change is slow. There is belief that markets require strong policy guidance and legislation/regulation to address inherent tendencies towards economic crisis, social conflict and environmental degradation. The tension between continuity of dominant values and greater equity for addressing key sustainability goals will not be easily reconciled.

- New sustainability paradigm: An ethos of 'one planet living' pervades and a fundamental questioning of progress emerges in light of sustainability goals. New socialeconomic arrangements and fundamental changes in values result in changes to the character of urban industrial civilisation, rather than its replacement.

- Fortress world: Powerful actors safeguard their own interests and resources at the expense of an impoverished majority who must live in ghettoes. The world is divided, with the elite in interconnected, protected enclaves and an impoverished majority outside. Armed forces impose order, protect the environment and prevent a collapse.

The key drivers adopted therein include, but are not limited to: societal, technological, economic, environmental, political and organisational - STEEPO (Ratcliffe, 2001) or PESTER (Shirley-Smith and Butler, 2008) where R denotes regulation, an important driver in the water field. The location of these scenarios in relation to two key drivers of change for water demand: 'technological' (technological efficiency) and 'social' (user behaviour) are shown in Figure 2. In this paper, in line with UK policy drivers the role of 'technological' changes alone (i.e. the vertical axis in Figure 2) is examined within the Luneside East boundary. The set of six different design cases (DC) for Luneside East is listed below (text in brackets describes how water demands change compared with the present)

DC1: Baseline (unchanged)

DC2: Soft policy (small decrease, equivalent to CSH 1 and 2)

DC3: Medium policy (medium decrease equivalent to CSH 3 and 4)

DC4: Strong policy (large decrease equivalent to CSH 5 and 6)

DC5: High demands (large increase)

DC6: Variable demands (large decrease for many and large increase for few).

Their location with respect to the UF scenarios (considered in this special issue), which include aspects of user behaviour, can be seen in Figure 2. DC1 considers average water consumption in the UK in 2011 and thus is centrally located. DC2 to DC4 can be considered as varying degrees of a 'policy reform' type scenario in that they do not seek to change behaviour but they do seek to change consumption patterns through a step change in the efficiency of the water-using technologies being adopted - leading to the best (i.e. most efficient) technologies being adopted in DC4. As such, DC4 is the closest comparator to a 'new sustainability paradigm' scenario in terms of the levels of water consumption being achieved, not least if alternative water sources - for example, greywater or RWH, are widely adopted and have been socially accepted. However, for it to reflect this scenario truly it would also require changes in behaviour to have occurred - for example, residents decide of their own free will to take shorter showers and not leave taps running etc. (Electris et al., 2009; Hunt et al., 2010b). These behavioural changes are not included within any of the design cases presented here for reasons outlined earlier. DC5 reflects very well the drivers behind 'market forces' in that the consumer is not worried about the amount of water they use and is more than happy to adopt highly consumptive water-using technologies (i.e. power showers). DC6 reflects very well the 


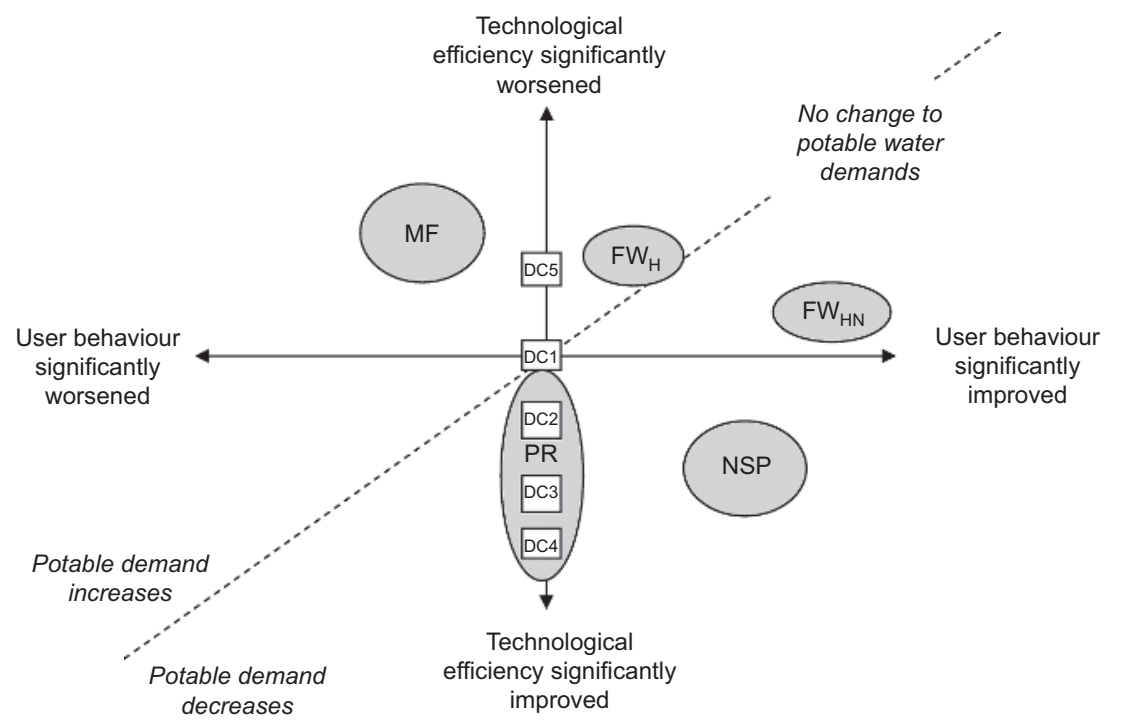

Figure 2. Design cases (DC) and urban futures scenarios (market forces (MF), new sustainability paradigm (NSP), policy reform (PR) and fortress world (FW))

'fortress world' scenario in that two levels of demand are considered; $\mathrm{FW}_{\mathrm{H}}-$ high water users $(35 \%$ of population) and $\mathrm{FW}_{\mathrm{HN}}$ - low water users $(65 \%$ of population) - the percentages adopted here are identical to those used in fortress world (Electris et al., 2009). They do not, however, include changes to user behaviour associated with $\mathrm{FW}_{\mathrm{HN}}$ - a world in which resources are rationed for the 'have-nots' and user behaviour, not by choice, has to change irrespective of the technologies adopted (these are likely to be older and less efficient because the cost to replace them is too great).

\subsection{Assumptions for water demand at site level}

The calculations performed here are undertaken based on a coarse level of detail for the site (e.g. site area of $66000 \mathrm{~m}^{2}, 350$ houses, $8000 \mathrm{~m}^{2}$ of workspace) and this is typical of the information likely to be available within the visioning stage of any regeneration programme. Based on this early information water consumption (i.e. potable and non-potable demands) and water outflow (i.e. stormwater and wastewater without the adoption of greywater and RWH infrastructure) within the six design cases are calculated. The data are presented in such a way that the differences between each design case can be easily compared and this is critical when considering the implications for water infrastructure requirements on site. Moreover, it is vitally important that these be investigated at this early stage within the decision-making process and then refined as more details become available. For example, the following high level assumptions within each design case have been made and would need to be refined or investigated further.
All 350 homes are assumed to be identical (i.e. same type and occupancy rates).

- All workspace is assumed to be offices (an approximate correlation is assumed to exist between demands per floor plate area and demands per employee, see Table 1).

- Occupancy, which can dramatically affect water demands, is assumed constant.

Water-using behaviour (e.g. duration of shower) is assumed unchanged.

- External water demands (e.g. gardens, hot tubs, car washing) are not included.

The effects of climate change are not included - that is, weather patterns are unchanged. This is in line with the need to understand relatively 'normal' events before including 'stressed' events within the infrastructure system (Nelson and Sterling, 2012).

- A range of standard UK technologies is adopted - that is, technologies such as 'in-sink' waste incinerators (i.e. garbage disposal as adopted in the USA; Jones et al., 2008) are not adopted (see section 2.3).

\subsection{Assumptions for water demand per person: water benchmarks and technology changes}

The benchmarks adopted within each design case are shown in Table 1. This section discusses how these benchmarks can be achieved simply through changes to technology (and its associated efficiency). This could be deemed to be within the control of both the developer and LCC and unlike human 
Design case

Domestic occupant - d

Office employee - o

Water benchmark adopted

Demand level (litres/person ${ }^{c}$ per day)

Demand level

\begin{tabular}{|c|c|c|c|}
\hline$D C 1-d$ & Typical UK & $147 \cdot 1$ & - \\
\hline DC1-0 & Typical UK & $24^{a}$ & $3 \cdot 6^{a}$ \\
\hline$D C 2-d$ & CSH level 1, 2 & 117 & - \\
\hline DC2-O & Typical UK -20\% & $19^{a}$ & $2 \cdot 8^{a}$ \\
\hline DC3-d & CSH level 3, 4 & 101 & - \\
\hline DC3-0 & Typical UK -40\% & $14^{b}$ & $1 \cdot 8^{\mathrm{b}}$ \\
\hline DC4-d & CSH level 5, 6 & 76 & - \\
\hline DC4-0 & Typical UK -64\% & $9^{a}$ & $0 \cdot 8^{a}$ \\
\hline DC5-d & Typical UK +30\% & 200 & - \\
\hline DC5-O & Typical UK +30\% & $31^{b}$ & $4 \cdot 5^{b}$ \\
\hline DC6-d & $35 \%(D C 5-d)+65 \%(D C 4-d)$ & 120 & - \\
\hline DC6-0 & $35 \%(\mathrm{DC} 5-0)+65 \%(\mathrm{DC} 4-0)$ & 17 & $2 \cdot 0$ \\
\hline
\end{tabular}

aBenchmarks adapted from Waggett and Arotsky (2006).

binterpolated.

'Person refers to occupant when used in terms of domestic properties and employee when used in terms of offices.

Table 1. Water benchmarks and demands (per person) within

Luneside East

\begin{tabular}{|c|c|c|c|c|c|c|}
\hline \multirow[b]{2}{*}{ Technology } & \multirow[b]{2}{*}{ Units } & \multicolumn{5}{|c|}{ Design case } \\
\hline & & DC1-d & $D C 2-d$ & DC3-d & DC4-d & DC5-d \\
\hline WC & l/flush & $6^{d}$ & $4 \cdot 5^{e}$ & $4 \cdot 5^{\mathrm{e}}$ & $2 \cdot 6^{\mathrm{e}}$ & $6^{d}$ \\
\hline Washing machine ${ }^{j}$ & $1 / \mathrm{kg}$ & $13^{2}$ & $10^{3}$ & $6 \cdot 1^{4}$ & $6 \cdot 1^{4}$ & $13^{2}$ \\
\hline Dishwasher & |/place setting & $1^{1}$ & $1^{1}$ & $1^{1}$ & $0 \cdot 7^{5}$ & $1^{1}$ \\
\hline $\operatorname{Sin}^{a}$ & |/person/day & $10 \cdot 4^{b}$ & $10 \cdot 4^{b}$ & $10 \cdot 4^{b}$ & $10 \cdot 4^{b}$ & $10 \cdot 4^{b}$ \\
\hline Shower & $1 / \min$ & $12^{9}$ & $8^{f}$ & $8^{f}$ & $6^{f}$ & $24^{c}$ \\
\hline Bath & Capacity to overflow (I) & $230^{h}$ & $230^{h}$ & $160^{h}$ & $97^{i}$ & $230^{h}$ \\
\hline Basin $^{a}$ & |/person/day & $1 \cdot 6^{\mathrm{b}}$ & $1 \cdot 6^{\mathrm{b}}$ & $1 \cdot 6^{\mathrm{b}}$ & $1 \cdot 6^{\mathrm{b}}$ & $1 \cdot 6^{\mathrm{b}}$ \\
\hline
\end{tabular}

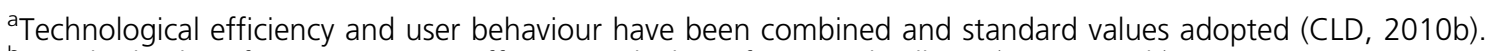

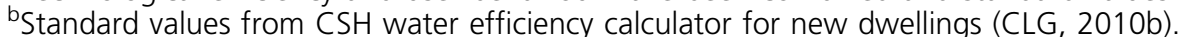

CPower shower.

${ }^{d}$ Maximum allowable flush volume in UK (The National Archives, 1999).

e(Grant, 2008).

f(Roebuck, 2007).

gLargest shower capacity allowed without permission being required from regulatory body.

${ }^{h}$ MTP (2008).

iSmallest bath available in the UK.

jModels adopted from Waterwise (2007a, 2007b): 'Zanussi ZWC1300W, ${ }^{2}$ Bosch SGS57E42, ${ }^{3}$ Hotpoint F541, ${ }^{4}$ AEG LL1620,

${ }^{5}$ Delonghi DL603W, ${ }^{6}$ Whirlpool GSG 9400 US.

Table 2. Assumptions for 'technological efficiency' in domestic homes 


\begin{tabular}{|c|c|c|c|c|c|}
\hline Technology & Units & This study ${ }^{a}$ & $U^{b}$ & Europe $^{c}$ & $U_{S A}^{d}$ \\
\hline WC & Flushes/person/day & $4 \cdot 42$ & $2 \cdot 2-5 \cdot 0$ & $2 \cdot 8-6 \cdot 3$ & $4 \cdot 76$ \\
\hline \multirow[t]{2}{*}{ Washing machine } & kg/person per day, use/person per day & $2 \cdot 1$ & - & - & - \\
\hline & & $0 \cdot 3^{e}$ & $0 \cdot 16-0 \cdot 34$ & $0 \cdot 05-0 \cdot 81$ & $0 \cdot 33$ \\
\hline \multirow[t]{2}{*}{ Dishwasher } & Place settings/use per day & $3 \cdot 6$ & - & - & - \\
\hline & Use/person per day & - & 0.71 & $0 \cdot 25-0 \cdot 71$ & $0 \cdot 4$ \\
\hline \multirow[t]{2}{*}{ Shower } & Min/shower per day & $4 \cdot 37^{f}$ & $3 \cdot 2-7 \cdot 15$ & - & $8 \cdot 7$ \\
\hline & Use/person per day & & $1 \cdot 43$ & $0 \cdot 75-2 \cdot 5$ & 1.97 \\
\hline Bath & $\begin{array}{l}\text { Volume filled/capacity to overflow } \times \\
\text { use/person per day }\end{array}$ & $0 \cdot 11^{9}$ & $--^{h}$ & $-^{h}$ & $-^{h}$ \\
\hline
\end{tabular}

${ }^{\mathrm{a}}$ From CSH water efficiency calculator for new dwellings (CLG, 2010b).

${ }^{b}$ Based on UK data reported in Chambers et al. (2005), Roebuck (2007) and EA (2007).

'Based on European data reported in Dimitrov (2004), Viera and Almeida (2007), Gascon et al. (2004), EA (2009) and EC (2009a, 2009b).

'Based on data from DeOreo et al. (2011) and Mayer et al. (1999).

${ }^{\mathrm{e}}$ Calculated assuming $7 \mathrm{~kg}$ max per load.

${ }_{5} .6$ if no bath adopted - units in this case are minutes/shower/person/day.

${ }^{9} 0.0$ if no bath adopted.

${ }^{h}$ Data for water use from faucets/taps (i.e. baths, basin, sinks) are sometimes given but typically not disaggregated.

Table 3. Assumptions for 'user behaviour' in domestic homes

behaviour is potentially better controlled through policy. A broader discussion around the potential implications of future behavioural changes in Luneside East can be found in Section 5.2. The way in which these respective benchmarks can be achieved in Luneside East through changes in technology alone is explained further in Sections 2.3.1 and 2.3.2.

\begin{tabular}{|c|c|c|c|c|c|c|}
\hline \multirow[b]{2}{*}{ Technology } & \multirow[b]{2}{*}{ Units } & \multicolumn{5}{|c|}{ Design case } \\
\hline & & DC1-o & DC2-0 & DC3-O & DC4-O & DC5-O \\
\hline WC & |/flush & $6^{d}$ & $4 \cdot 5^{e}$ & $3 \cdot 6^{\mathrm{e}}$ & $2 \cdot 6^{\mathrm{e}}$ & $6^{d}$ \\
\hline Urinal & l/flush & $2 \cdot 5^{f}$ & $1 \cdot 5^{\mathrm{g}}$ & $1 \cdot 5^{9}$ & $0 \cdot 0^{h}$ & $2 \cdot 5^{f}$ \\
\hline Dishwasher & |/place setting & $1 \cdot 14^{1}$ & $1^{2}$ & $1^{2}$ & $0 \cdot 7^{3}$ & $1^{1}$ \\
\hline Sink & I & $4 \cdot 0^{a}$ & $4 \cdot 0^{a}$ & $1 \cdot 7^{\mathrm{b}}$ & $1 \cdot 7^{\mathrm{b}}$ & $4 \cdot 0^{a}$ \\
\hline Shower & $1 / \min$ & - & - & - & - & $12^{i}$ \\
\hline Basin & I & $1 \cdot 6^{\mathrm{c}}$ & $1 \cdot 6^{c}$ & $1 \cdot 6^{\mathrm{c}}$ & $1 \cdot 6^{\mathrm{c}}$ & $1 \cdot 6^{c}$ \\
\hline
\end{tabular}

aHighest flow rate in UK.

bowest flow rate in UK (aerated tap).

'Standard value used in domestic homes (CLG, 2010b)

dMaximum allowable flush volume in UK (The National Archives, 1999).

e(Grant, 2008).

f $80 \mathrm{l} / \mathrm{h}$ flush capacity with employee use rate (hourly) to flush capacity ratio of 0.4 .

${ }^{9}$ Maximum allowable single flush unit allowed under UK building regulations.

hWaterless office urinal system (http://www.waterlessurinals.co.uk/about-waterless-urinals).

'Largest shower capacity allowed without permission being required from regulatory body.

Models adopted: ${ }^{1}$ New World FDW600W, '2Bosch SGS57E42, '3 Delonghi DL603W (Waterwise, 2007a, 2007b).

\subsubsection{Domestic demands (per occupant)}

A set of six design cases for domestic demands (per occupant) in Luneside East has been derived using the water efficiency calculator for new dwellings (CLG, 2010b). The calculator is the government's national calculation methodology for assessing water efficiency in new dwellings. As such, it supports the code for sustainable homes, May 2009 and subsequent

Table 4. Assumptions for 'technological efficiency' in offices 
Engineering Sustainability

Volume 165 Issue ES1
Urban futures and the code for

sustainable homes

Hunt, Lombardi, Farmani, et al. versions, the Building Regulations (2000) (as amended) and the Building (Approved Inspector, etc.) Regulations (2000) (as amended). The technologies adopted and their related performances have been taken from appropriate literature (Table 2). In order to calculate the volume of water used by each occupant these need to be multiplied by a factor related to user behaviour (Table 3). In this study factors are taken directly from the water efficiency calculator for new dwellings (CLG, 2010b), and for direct comparison data for user behaviour found within other studies (i.e. UK, Europe and USA) are shown. The total amount of water used by an individual is shown in Table 1, the breakdown of demands is shown in Figure 3 . The value of $26.5 \mathrm{l} /$ person per day for water closet (WC) flushing in DC1-d (Figure 3), for example, is calculated by multiplying 6 1/flush (Table 2) by 4.42 flushes/person per day (Table 3 ). In some cases standard values are given (e.g. sinks and basins) and thus no factors are required. Figure 3 shows the subsequent demands (broken down by end use) across all design cases.

When considering the design cases in turn (Table 2) it can be seen that changes in demand (as compared with the baseline DC1-d) have been achieved as follows: DC2-d adopts a reduced flow rate shower and smaller WC cistern in addition to a more efficient washing machine. DC3-d adopts the same shower system and WC cistern as DC2-d; however, it increases further the efficiency of the washing machine and reduces the size of the bath. DC4-d adopts the washing machine as DC3-d; however, it reduces further the size of the bath, shower and WC cistern, in addition it adopts a more efficient dishwasher. DC5-d adopts the same technologies as DC1-d excepting the adoption of a less efficient washing machine and a more waterintensive power shower.

\subsubsection{Office demands (per employee)}

Unlike domestic dwellings there is no 'water efficiency calculator for offices' or a 'code for sustainable offices', therefore this research has derived a comparable approach to that taken in Section 2.3.1 using benchmarks originally formulated by Waggett and Arotsky (2006), as shown in Table 1. These benchmarks were used in the derivation of policies $(d)$ and $(e)$, as outlined in Section 1, thus are directly relevant here. The resulting assumptions, as comparable with Tables 2 and 3, are shown in Tables 4 and 5. The factors were calculated by back-analysis of data from Waggett and Arotsky (2006), who reported the following breakdown in demand: $43.5 \%$ for WC, $20 \cdot 5 \%$ for urinals, $27 \%$ for washing and $10 \%$ for canteen, kitchen and cleaning (assumed here to be split 3:7 for basin and dishwasher use). This breakdown is representative of the 'baseline' adopted in DC1-o (Figure 4).

When considering the design cases in turn (Table 4) it can be seen that changes in demand (as compared with the baseline DC1-o) have been achieved as follows: DC2-o adopts a more water-efficient dishwasher and smaller WC cistern and urinal flush unit. DC3-o adopts the same technologies as DC3-o excepting the adoption of a more efficient dual-flush WC cistern. DC4-o adopts the same washing machine as DC3-o. However, it increases further the efficiency of showers, WC cisterns, urinals (now waterless) and dishwashers. DC5-o adopts the same technologies as DC1-o, except for the addition of shower facilities.

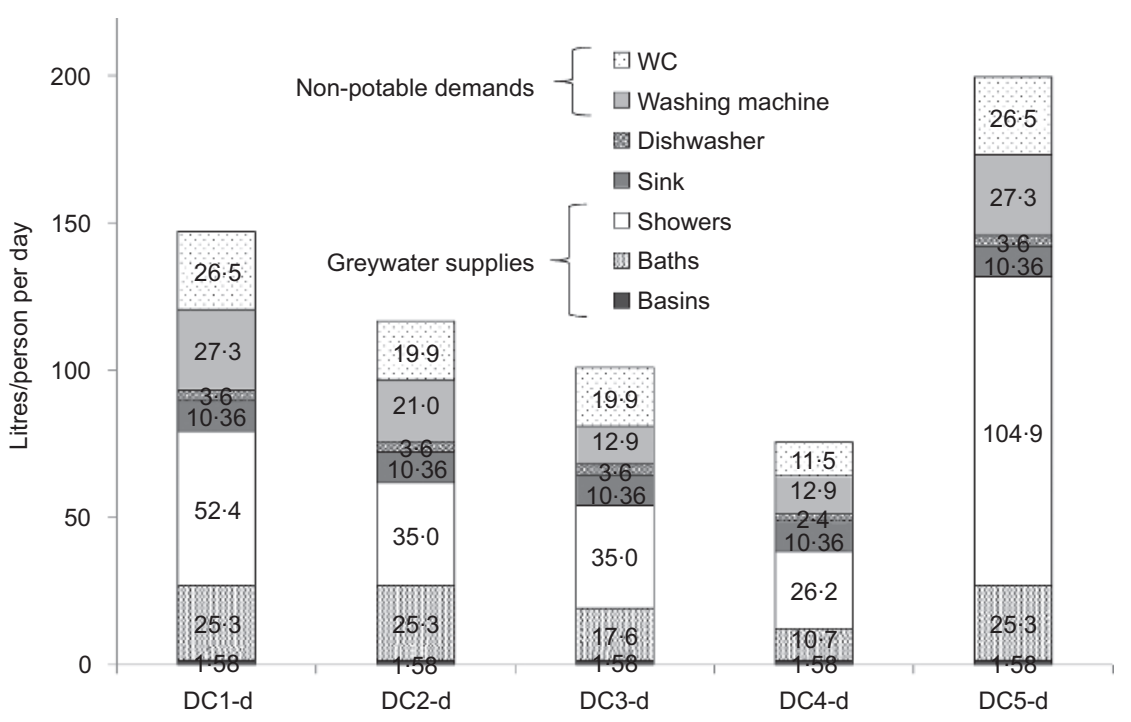

Figure 3. Domestic water demand profile per occupant 


\begin{tabular}{|c|c|c|c|c|c|}
\hline Technology & Units & This study ${ }^{a}$ & BREEAM $(U K)^{\mathrm{b}}$ & Europe range ${ }^{c}$ & USA $^{d}$ \\
\hline WC & Flushes/person per day & $1 \cdot 7$ & $1 \cdot 3$ & $-g$ & $2 \cdot 6$ \\
\hline Urinal & Use/person per day & $1 \cdot 9$ & $2 \cdot 0$ & $-g$ & $1 \cdot 25$ \\
\hline \multirow[t]{2}{*}{ Dishwasher } & Place settings/use per day & 0.5 & - & $-g$ & - \\
\hline & Use/person per day & - & - & $-g$ & - \\
\hline \multirow[t]{2}{*}{ Sink } & Min/person per day & $1 \cdot 6^{f}$ & - & $-g$ & - \\
\hline & Use/person per day & - & $2 \cdot 5$ & $-g$ & $3 \cdot 85$ \\
\hline \multirow[t]{2}{*}{ Shower } & Min/shower per day & $4 \cdot 37^{\mathrm{e}}$ & - & $-g$ & - \\
\hline & Use/person per day & $0 \cdot 14^{f}$ & $0 \cdot 1$ & $-g$ & - \\
\hline
\end{tabular}

a Values derived from back-analysis of UK data reported by Waggett and Arotsky (2006).

${ }^{b}$ Taken from the Building Research Establishment Environmental Assessment Method (BREEAM) calculator for buildings (including offices).

'Based on data reported by Dziegielewski et al. (2000) and Pacific Institute (2003).

${ }^{\mathrm{d}}$ Based on data from De Oreo et al. (2011) and Mayer et al. (1999)

eValue as adopted in domestic homes (CLG, 2010b).

fOne use per week assumed.

${ }^{9}$ Substantial data are available for breakdown by end-use - but not behaviour.

Table 5. Assumptions for 'user behaviour' in offices

\section{Water infrastructure analysis: results}

In this section quantification of both potable and non-potable demands, in the light of technological changes imposed (Section 2), is assessed for domestic properties and offices within Luneside East considering two different scales - that is, individual property (Section 3.1.1) and development (Section 3.1.2). Subsequently, Sections 3.2 and 3.3, respectively, consider how greywater recycling and RWH can be used to meet these non-potable demands and assess the impact this would have on wastewater and stormwater infrastructure requirements. For calculation purposes it has been assumed that no leakage occurs within the network systems; however, as infrastructure ages the probability of leakage/bursts occurring will necessitate increased volumes of non-potable water supply.

\subsection{Potable and non-potable demands}

3.1.1 Individual scale: demands per occupant/employee It is assumed throughout that non-potable demands come from washing machines, WCs and urinals (Legget et al., 2001a, 2001b; Mustow and Grey, 1997). Figures 3 and 4 show the daily demands per person - that is, occupant or employee for

Design case

All domestic properties - D

All office space - O

No. of units Floor area: $\mathrm{m}^{2}$

Total demands:

Non-potable
demands: $\mathrm{m}^{3} /$ day

Greywater $\mathrm{m}^{3} /$ day

$108 \cdot 1$

$28 \cdot 2$

$85 \cdot 8$

$22 \cdot 7$

$74 \cdot 1$

$14 \cdot 6$

$55 \cdot 6$

$6 \cdot 4$

$146 \cdot 7$

$33 \cdot 6$

$87 \cdot 0$

$15 \cdot 9$

$39 \cdot 6$

$17 \cdot 9$

$30 \cdot 1$

$12 \cdot 6$

$24 \cdot 1$

$9 \cdot 5$

$17 \cdot 9$

$3 \cdot 1$

$39 \cdot 6$

$16 \cdot 2$

$25 \cdot 5$

$7 \cdot 7$ produced: $\mathrm{m}^{3} /$ day

DC6-D 350

8000

Table 6. Total water demands on site for Luneside East 
Engineering Sustainability

Volume 165 Issue ES1
Urban futures and the code for

sustainable homes

Hunt, Lombardi, Farmani, et al.

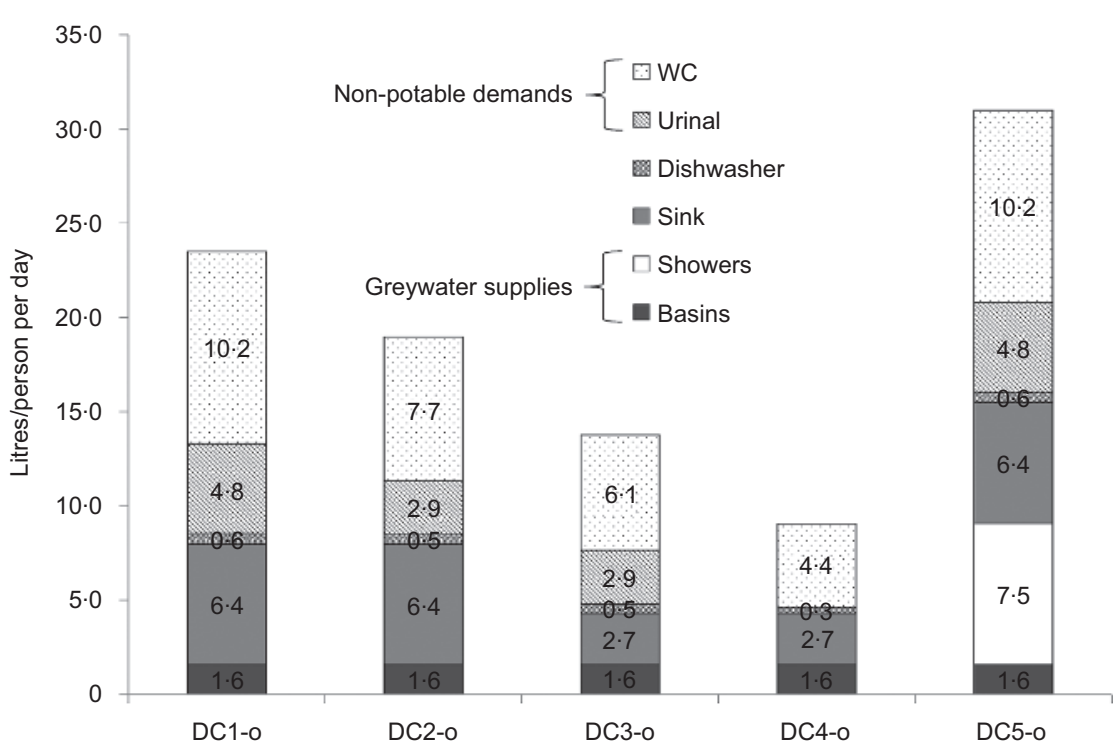

Figure 4. Office water demands profile per employee

domestic properties and offices, respectively. It can be seen that the lowest non-potable demands occur in DC4-d (domestic) and DC4-o (office). In contrast, the highest non-potable demands occur in DC1-d, DC1-o and DC5-d, DC5-o. For domestic properties the percentage non-potable over total demands - that is, potable plus non-potable, ranges from $27 \%$ (DC5-d) to $36 \%$ (DC1-d). In contrast, the ratio for offices ranges from $41 \%$ (DC5-o) to $190 \%$ (DC3-o).

If it were assumed that non-potable domestic demands (e.g. WC flushing and washing machines) were met through nonpotable supply sources - for example, greywater (Section 3.2), rainwater (Section 3.3), reclaimed industrial process water or water abstracted from boreholes/wells, there is the potential to improve significantly the sustainable performance therein (Butler et al., 2010); here sustainability performance is measured as the percentage of non-potable demands that can be met through non-potable sources. The motivation here is to achieve $100 \%$ and replace, when possible, very clean drinkable quality mains water with water of a lower quality - that is, from a non-potable source. If domestic non-potable demands per person in Luneside East (Figure 3) were supplied through non-potable sources the following changes would occur: the requirement for mains water in DC1-d would be reduced from $147 \cdot 1$ to $93 \cdot 3$ 1/occupant per day (53.8 1/occupant per day being supplied through non-potable sources) and in so doing would achieve the same performance level as CSH level 4 (i.e. $<1051$ mains water/occupant per day). In the same manner the performance levels in DC2-d and DC3-d would surpass CSH level 6 (i.e. <80 1 mains water/occupant per day). Moreover, when implemented in DC4-d the level of performance achieved is not dissimilar to the UK baseline value for the 1950s or the minimum requirement to live currently (i.e. almost 501 mains water/occupant per day), as stipulated by the United Nations (Chenoweth, 2007; UN, 2003).

\subsubsection{Development scale: total demand for the site}

The total demands for the site (i.e. at development scale) as shown in Table 6 can be calculated according to Equation 1

\section{Total demand $=A+B$}

where $A$ is the number residents $\times$ demand per occupant and $B$ is the office floor area $\times$ demand per floor area.

The number of residents is found by multiplying the number of domestic units by an occupancy rate for the UK, assumed to be 2.1, as consistent with Roebuck (2007). The assumed relationship between office demands per floor area and office demands per employee are given in Table 1. The non-potable demands (hence potable demands) in domestic dwellings and offices can be seen in Figures 3 and 4.

Table 6 shows the total demands (potable and non-potable) for the site calculated according to Equation 1. It can be seen that the maximum daily capacity requirements for Luneside East in the absence of any non-potable water supplies would be $182.5 \mathrm{~m}^{3} /$ day $\left(146.7 \mathrm{~m}^{3} /\right.$ day $+33.6 \mathrm{~m}^{3} /$ day $)$ in DC5. In contrast, the minimum requirement, if all non-potable requirements were met by non-potable sources, would be $41.0 \mathrm{~m}^{3} /$ day $\left(55.6 \mathrm{~m}^{3} /\right.$ day $+6.4 \mathrm{~m}^{3} /$ day $-17.9 \mathrm{~m}^{3} /$ day $3 \cdot 1 \mathrm{~m}^{3} /$ day) in DC4 - less than one quarter of the maximum. 
Engineering Sustainability

Volume 165 Issue ES1
Urban futures and the code for

sustainable homes

Hunt, Lombardi, Farmani, et al.
This is important knowledge before development, not least because the developer is required to pay for new metered water supply infrastructure to the site. The volumes of greywater produced are also shown; these are explored further in Section 3.2 .

\subsection{Greywater recycling and wastewater infrastructure requirements}

Greywater recycling (i.e. water collected from basins, baths and showers only; Legget et al., 2001a, 2001b) is considered by many to be a sustainable source of non-potable water supply that can reduce wastewater outflow. It can be seen from Figures 3 and 4 that the volume of greywater produced varies significantly across design cases and this is because its production is highly dependent on the technologies being adopted within the home (basins, baths and showers) or office (basins and showers), their respective efficiencies (Tables 2 and 4 ) and the role of user behaviour (Tables 3 and 5). (As mentioned previously the user behaviour is assumed constant in all design cases in order that the impacts of technology efficiency on greywater production are assessed.) The long-term success of a greywater solution in any design case depends on whether sufficient greywater can be produced to meet non-potable demands. Although granted it may also depend on the social acceptability of using greywater (ones own or perhaps even other peoples; Jeppeson, 1996). With minimal treatment processes (assumed here) storage requirements are limited to a 24-h period to avoid bacterial growth (Tal et al., 2011) and while longer retention times are possible this requires more complex (energy-intensive) treatment processes, in addition to larger storage capacities.
From inspection of Figures 3 and 4 it can be seen that the greatest volumes of domestic greywater are produced within DC1-d and DC5-d (131 1/person per day); this could be considered the maximum daily storage requirement if minimal treatment processes were adopted and is more than three times that produced in DC4-d (38 1/person per day). In addition, there is 10 times as much office greywater produced in DC5-o (16 1/person per day) compared with DC1-o to DC4-o (1.6 1/ person per day); the effect on greywater production through adopting a shower is very evident.

Figure 5 shows the deficit/surplus when domestic greywater is used to meet non-potable domestic demands and office greywater is used to meet non-potable office demands. All six design have cases in which non-potable domestic demands can be met with surplus (ranging from 10 1/person per day in DC4-d to 57 1/person per day in DC5-d). However, for offices non-potable demands would not be met in any design case that is, there is a deficit (ranging from 9.91 /person per day in DC1-o to $1 \cdot 2$ 1/person per day in DC5-o). The surplus supply of greywater from domestic buildings is, however, sufficient to meet the deficit created from office buildings should such a solution be required (Zadeh et al., 2010), although this would assume that using other people's greywater is a widely acceptable practice. Alternatively, adoption of less efficient technologies that produce more greywater could resolve the situation within certain design cases - that is, an important balance, which at face value may be counter to what would naturally be considered. For example, if the 121 shower was swapped for a 241 power shower in DC5-o a surplus of

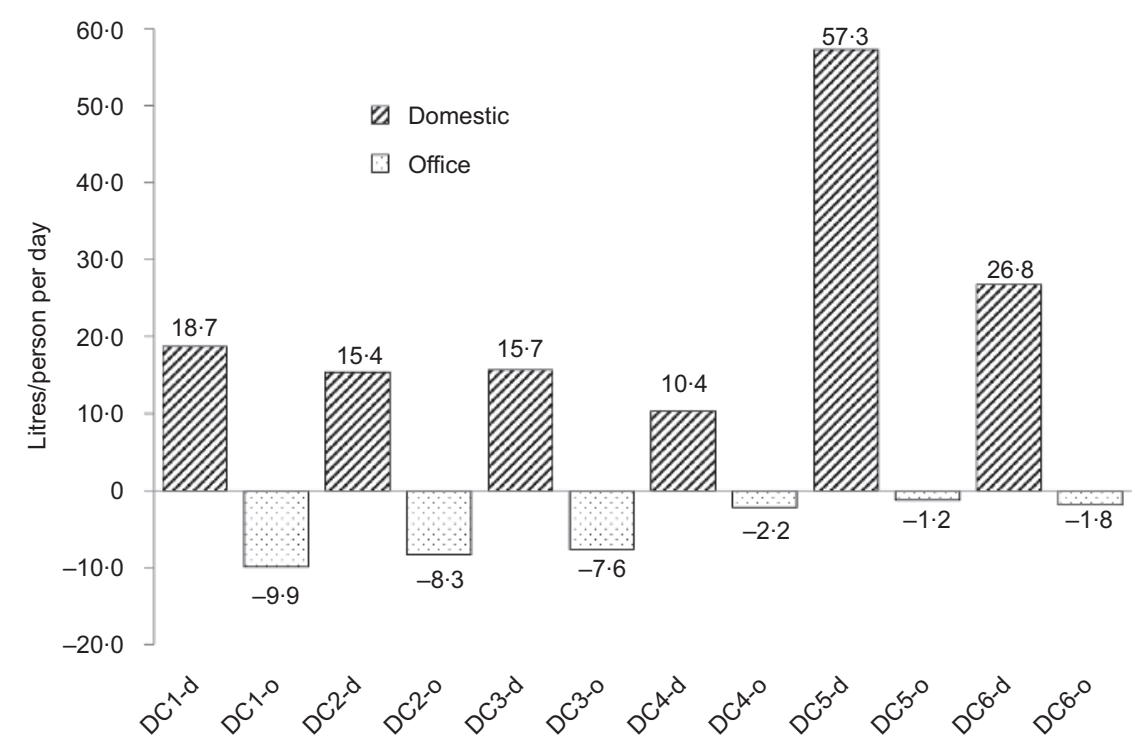

Figure 5. Daily greywater deficit/surplus when meeting non-

potable demands 
Engineering Sustainability

Volume 165 Issue ES1
Urban futures and the code for

sustainable homes

Hunt, Lombardi, Farmani, et al.

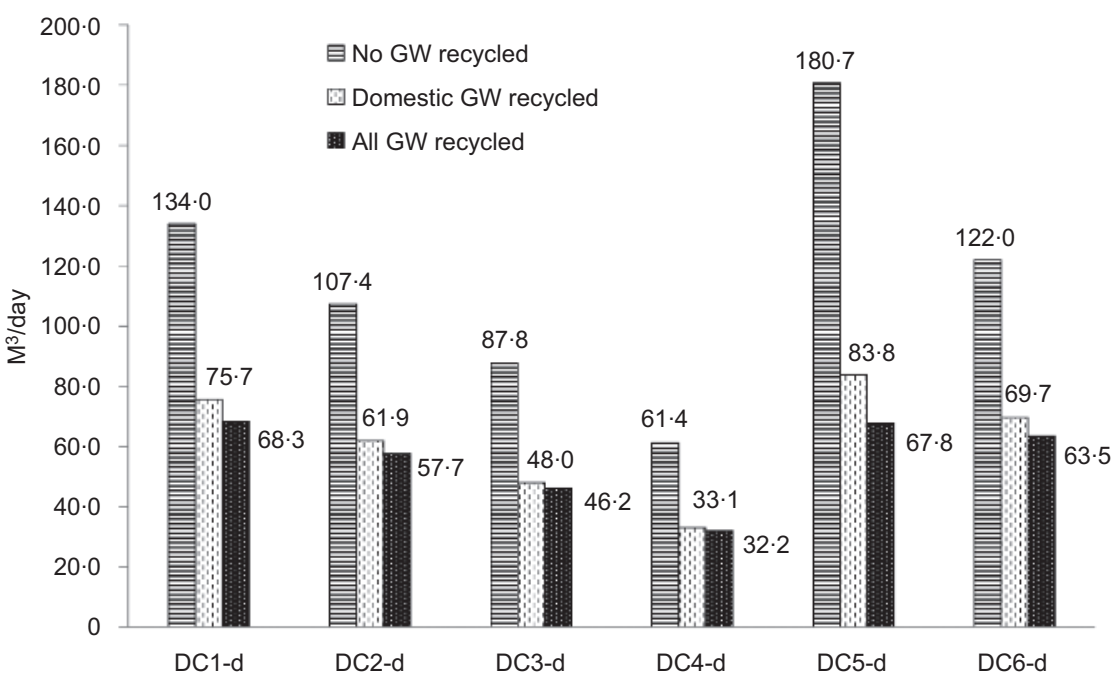

Figure 6. Effect of greywater (GW) recycling on total wastewater outflow

greywater would be created indicating a greywater system could successfully be implemented.

The adoption of greywater recycling systems in Luneside East would reduce sewer outflow providing economic savings in terms of lower capacity infrastructure requirements. Figure 6 shows the volume of wastewater outflow in Luneside East as a consequence of: (a) no greywater being recycled; (b) greywater being recycled only within domestic dwellings; and (c) grey-

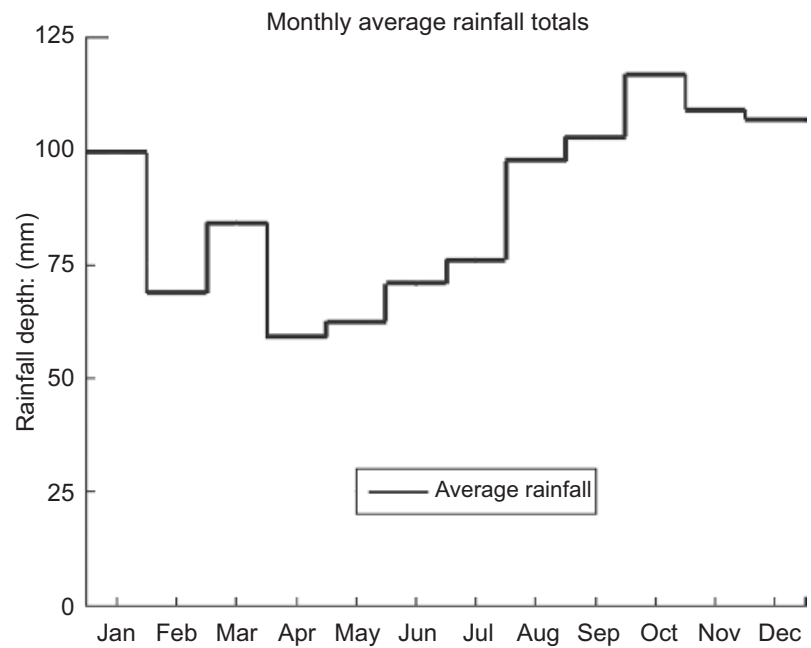

Figure 7. Average rainfall data 1966-1998 (Lancaster University, 2010) water being recycled in both domestic dwellings and offices (it is assumed surplus greywater from domestic dwellings is used within offices). It can be seen that the highest outflow rate to the sewer $\left(180.7 \mathrm{~m}^{3} /\right.$ day) occurs in DC5-d when no greywater is recycled, whereas the lowest outflow $\left(32.2 \mathrm{~m}^{3} /\right.$ day) occurs in DC4-d when demands have been reduced significantly and all greywater has been recycled. The smallest outflow rate $\left(32.2 \mathrm{~m}^{3} /\right.$ day $)$ is almost one sixth of the largest outflow $\left(180 \cdot 7 \mathrm{~m}^{3} /\right.$ day $)$ and would therefore require significantly different wastewater infrastructure capacity - that is, the internal diameter of the pipes may need to be changed in order to avoid operational difficulties. In other words, if the capacity of the wastewater infrastructure had been designed to levels required for design DC5-d (highest outflow in absence of greywater recycling, Figure 7) and yet the development performed to levels in DC4-d (lowest outflow in absence of greywater recycling) it may not be sufficient to self-cleanse (Butler et al., 2003; Butler and Davies, 2011). The largest reduction in outflow, and thus the greatest impact achieved through adoption of a greywater system, occurs in DC4-d when all greywater is recycled. Here the outflow is reduced by $74 \%$ from $180 \cdot 7$ to $67 \cdot 8 \mathrm{~m}^{3} /$ day. The outflow is slightly less than that occurring in DC1-d $\left(68.3 \mathrm{~m}^{3} /\right.$ day $)$ and yet the total demands were significantly greater (Table 6). It should also be recognised that the payback period for non-potable supply systems (payback being measured in terms of the volume of mains water that is being substituted) increases as the volumes of greywater being used decreases (Memon et al., 2005). If small-scale systems were adopted in Luneside East, DC4-d would have a payback period $2 \cdot 7$ times longer than DC1-d and DC5-d. 
Engineering Sustainability

Volume 165 Issue ES1
Urban futures and the code for

sustainable homes

Hunt, Lombardi, Farmani, et al.

\subsection{Rainwater harvesting and stormwater infrastructure requirements}

RWH is also considered by many to be a sustainable source of non-potable water supply, which has implications for stormwater infrastructure provision. Therefore, an analysis of RWH must then equally be set against the context of reducing flash flood risk on site (and downstream) through the adoption of underground water storage tanks as part of a larger SUDS (Wilson et al., 2004; Woods-Ballard, 2007). Stormwater outflow volumes are directly related to the volume of rain that falls on site and subsequently enters the stormwater system, commonly referred to as 'runoff'. This in turn is a function of: rainfall profile (i.e. magnitude and duration that is influenced directly by geographical location); surface area of the site; and surfacing materials adopted (e.g. impermeable surfaces that prevent natural attenuation and increase runoff and permeable surfaces, including SUDS, which allow for natural attenuation and reduce runoff). Stormwater volumes are therefore directly affected by the adoption of RWH systems in which rainwater is collected from roofs, for re-use as a non-potable source of water supply. Runoff taken from other impermeable surfaces is called 'storm water harvesting' and while not widely practised in the UK it is becoming popular in places such as Australia (Hatt et al., 2006). For the purposes of this research only RWH systems are considered and it is assumed that $70 \%$ of all water that falls on rooftops can be collected, as identified in the water efficiency calculator for new dwellings (CLG, 2010b). This represents a 50:50 split between sloped and flat surfaces in which an average value of $90 \%$ and $50 \%$, respectively, can be collected (Leggett et al., 2001a, 2001b). The key issue in the success of these systems is in providing sufficient volume of storage for year-round performance. In this paper it is assumed that rainwater is collected from roofs $\left(40 \mathrm{~m}^{2}\right.$ per household assumed) and directed towards individual storage tanks (i.e. one underground tank per dwelling) and then pumped, when required, to meet respective non-potable demands.

Monthly average rainfall figures adopted for Luneside East are shown in Figure 7. The data represent average rainfall figures collected over a 30-year period at the Hazelrigg weather station (University of Lancaster). It can be seen that the maximum and minimum monthly rainfall values, respectively, are $117 \mathrm{~mm}$ in October and $58 \mathrm{~mm}$ in April (Figure 7). Owing to its close proximity to Luneside East (c. $6 \mathrm{~km}$ away) these values are assumed to be representative, although they should be treated with care when converted to daily values, as assumed here. The dynamics of the filling and emptying of the tanks is crucial to the success of RWH and has been investigated by Fewkes and Butler (2000) in addition to being incorporated in water modelling tools such as UWOT (Makropoulos et al., 2008), for example. Figure 8 shows water levels within Luneside East's domestic scale RWH tanks calculated over a 2-year period using a yield-before-storage approach (Mitchell, 2007). It is assumed that empty tanks are installed in January of the first year. Tanks are sized according to BS 8515 (BSI, 2009) - that is, the volume required is the lesser of $5 \%$ collectable annual rainfall and 5\% annual non-potable demands, leading to the following tank sizes being adopted: 18861 for DC1-d and DC5-d; 15671 for DC2-d; 12531 for DC3-d; and 9311 for DC4-d. Assuming year 2 is representative of long-term performance, it can be seen that the tanks in DC1-d and DC5-d have sufficient stored capacity to meet demands from August through to May;

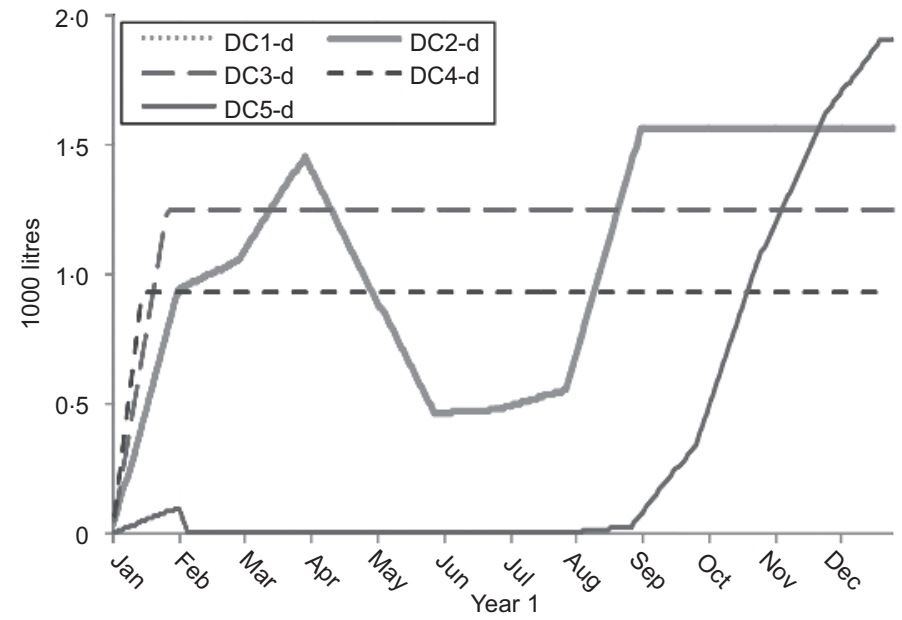

(a)

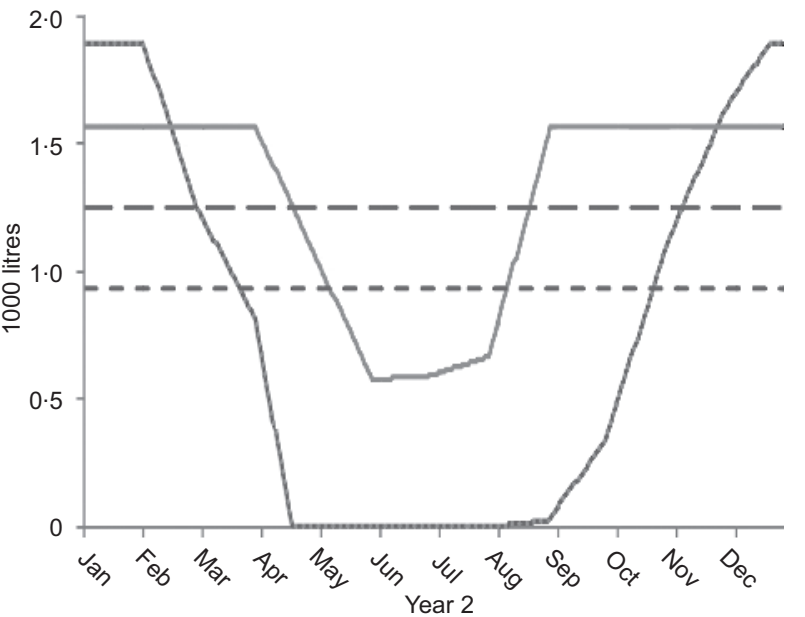

(b)

Figure 8. Water volumes within domestic RWH tanks $\left(40 \mathrm{~m}^{2}\right.$ pitched roof) 
Engineering Sustainability

Volume 165 Issue ES1
Urban futures and the code for

sustainable homes

Hunt, Lombardi, Farmani, et al.

\begin{tabular}{|c|c|c|c|c|c|c|}
\hline \multirow{2}{*}{$\begin{array}{l}\text { Design case } \\
\text { Domestic and office }\end{array}$} & Per household & Per 350 households & Per $\mathrm{m}^{2}$ office ${ }^{a}$ & Per $8000 \mathrm{~m}^{2}$ office & \multicolumn{2}{|c|}{ Total area required } \\
\hline & $m^{2}$ & $\mathrm{~m}^{2}$ & $\mathrm{~m}^{2}$ & $m^{2}$ & $\mathrm{~m}^{2}$ & $\begin{array}{l}\% \\
\text { site }\end{array}$ \\
\hline DC1 & 86 & 30100 & $1 \cdot 7$ & 13600 & 43700 & 66 \\
\hline DC2 & 66 & 23100 & $1 \cdot 2$ & 9600 & 32700 & 50 \\
\hline DC3 & 53 & 18550 & 0.9 & 7200 & 25750 & 40 \\
\hline DC4 & 39 & 13650 & $0 \cdot 3$ & 2400 & 16050 & 24 \\
\hline DC5 & 86 & 30100 & $1 \cdot 7$ & 13600 & 43700 & 66 \\
\hline DC6 & 56 & 19600 & $0 \cdot 8$ & 6400 & 26000 & 40 \\
\hline
\end{tabular}

${ }^{a}$ Non-potable demands $/ \mathrm{m}^{2}$ taken from Table 3 (floor space is approximately $7 \mathrm{~m}^{2}$ per employee (Waggett and Arotsky, 2006).

Table 7. Minimum roof collection area to meet non-potable demands

however, they are empty (i.e. require potable mains water input) from May to July. The RWH tank in DC2-d is not empty at any time during the year; however, its storage volume decreases from April to July, RWH tanks in DC3-d and DC4-d are not empty at any time during the year - these tanks fill very quickly in year 1 and remain full. If non-potable demands were to be met year round in DC1-d, DC2-d and DC5-d a roof space larger than $40 \mathrm{~m}^{2}$ would be required, in contrast a smaller roof area could be adopted in DC4-d. Table 7 shows the respective roof sizes that would perfectly match yearly demands in each design case. These are calculated by dividing yearly non-potable demands by collectable yearly rainfall (assuming 70\% water can be collected). The total roof areas on site are calculated and given as a percentage of the total site area $\left(66000 \mathrm{~m}^{2}\right)$. It can be seen that a maximum of $66 \%$ site area would need to be covered in roof space to meet non-potable demands within DC1 and DC5, compared with a minimum of $24 \%$ site area in DC4. In other words, in each design case there is a minimum threshold for the area of impermeable roof surfaces to be adopted if non-potable demands are to be met through RWH. This may lead to trade-offs being made with the adoption of other solutions (e.g. wider adoption of SUDS surfaces, green roofs) in high water using design cases (e.g. DC1 and DC5).

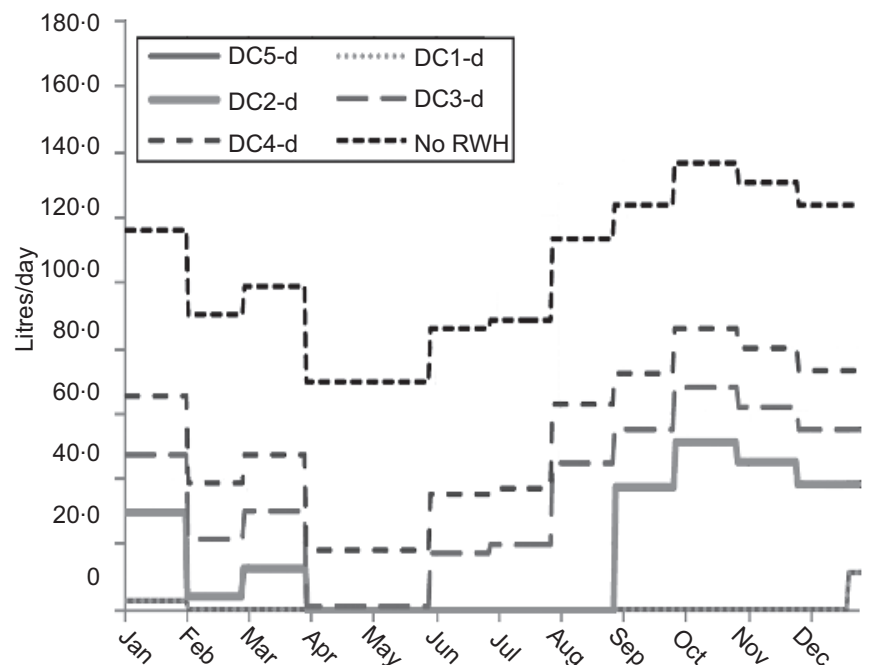

(a)

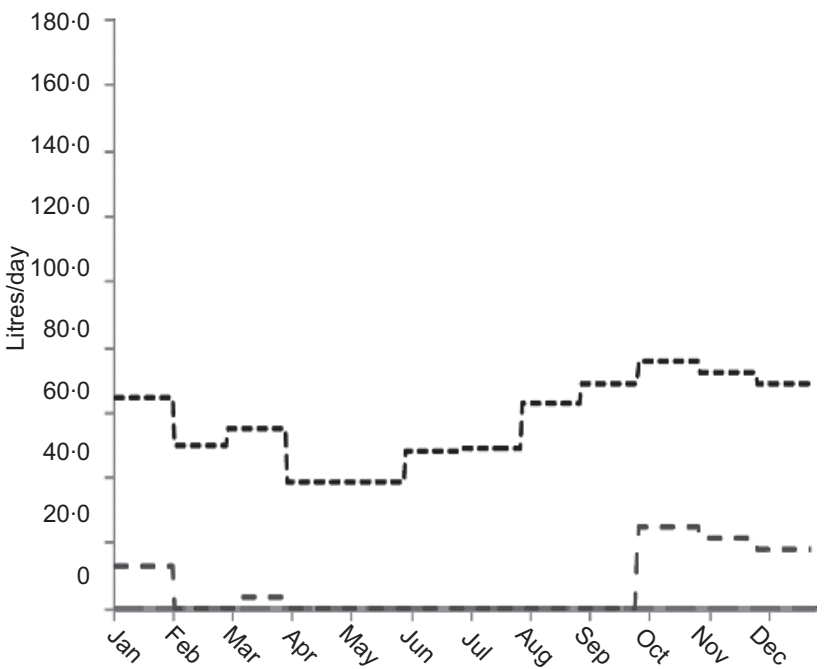

(b)

Figure 9. Effect of RWH on stormwater outflow (year 2) (a) $40 \mathrm{~m}^{3}$ pitched roof; (b) $40 \mathrm{~m}^{3}$ flat roof 
Urban futures and the code for

sustainable homes

Hunt, Lombardi, Farmani, et al.
It is assumed that RWH tanks overflow to the stormwater system and Figure 9 shows the subsequent outflows of roof-related rainfall when adopting $40 \mathrm{~m}^{2}$ of pitched and flat roofs, respectively. It can be seen that DC1-d and DC5-d have the most impact on reducing outflow compared with the baseline (no RWH); in contrast DC4-d has the least impact. A flat roof reduces the outflow by almost half compared with a pitched roof (Figure 9b) with very little outflow occurring in DC1-d, DC2-d, DC3-d and DC5-d throughout the year. However, there is a trade-off with the amount of non-potable water that can be collected. There may also be trade-offs in terms of energy, space requirements and maintenance and, while they have not been covered in this paper, they should not be ignored.

\section{Sustainability and resilience}

The management and development of local infrastructure has shifted away from a concern with sustainability towards approaches that integrate sustainability with resilience (Rogers et al., Resistance and resilience - paradigms for critical local infrastructure, in preparation). In general terms a loss of system performance or quality from a specific event (here assumed to be technological changes) can be used as a proxy for a loss in resilience (Bruneau et al., 2003) in which engineering resilience is assumed to be stability near an equilibrium state (Holling, 1996). Drawing from the findings of Section 3 it might be assumed that DC4 provides the least unsustainable solution based on a substantial increase in the performance of technologies, and that this leads to improved resilience within the network. However, this simply ignores the fact that there are many interdependencies within the network that are, as yet, poorly understood (Nelson and
Sterling, 2012). While high performance and resilience may be achieved in one area, the interdependencies within a network may mean that this is to the detriment of performance in another (Table 8). A handful of the interdependencies are discussed below, the way in which performance is measured is detailed for each and design cases are ranked in order of the performance/resilience they provide - that is, first means highest performance/resilience.

\subsection{Water supply}

The volumes required in Luneside East are dependent on what technologies are adopted and user behaviour within homes and offices. In addition, this will be impacted upon by the adoption of non-potable supplies, greywater and RWH. The reduction in potable demands compared with the baseline is a measure of sustainable performance, as long as these supplies are available - that is, DC5 performs worst (demand increases by a third) and DC4 performs best (demand is quartered compared with baseline). This has added benefits in terms of the resilience to a growing population as a population four times bigger could be served. However, the performance of the development to meet non-potable needs during drought/mains failure may be different and depends on the following: duration of drought, volume of non-potable water stored (or being supplied), duration of storage (24-48 h for greywater (Dixon et al., 1999a, 1999b; Tal et al., 2011) and up to 30 days for rainwater, Leggett et al., 2001a) and how much water is drawn off daily (i.e. non-potable demands). If the 'number of days worth of stored non-potable water' is used as a measure of sustainable performance, it can be seen that DC4 would be able to meet non-potable demands for the longest

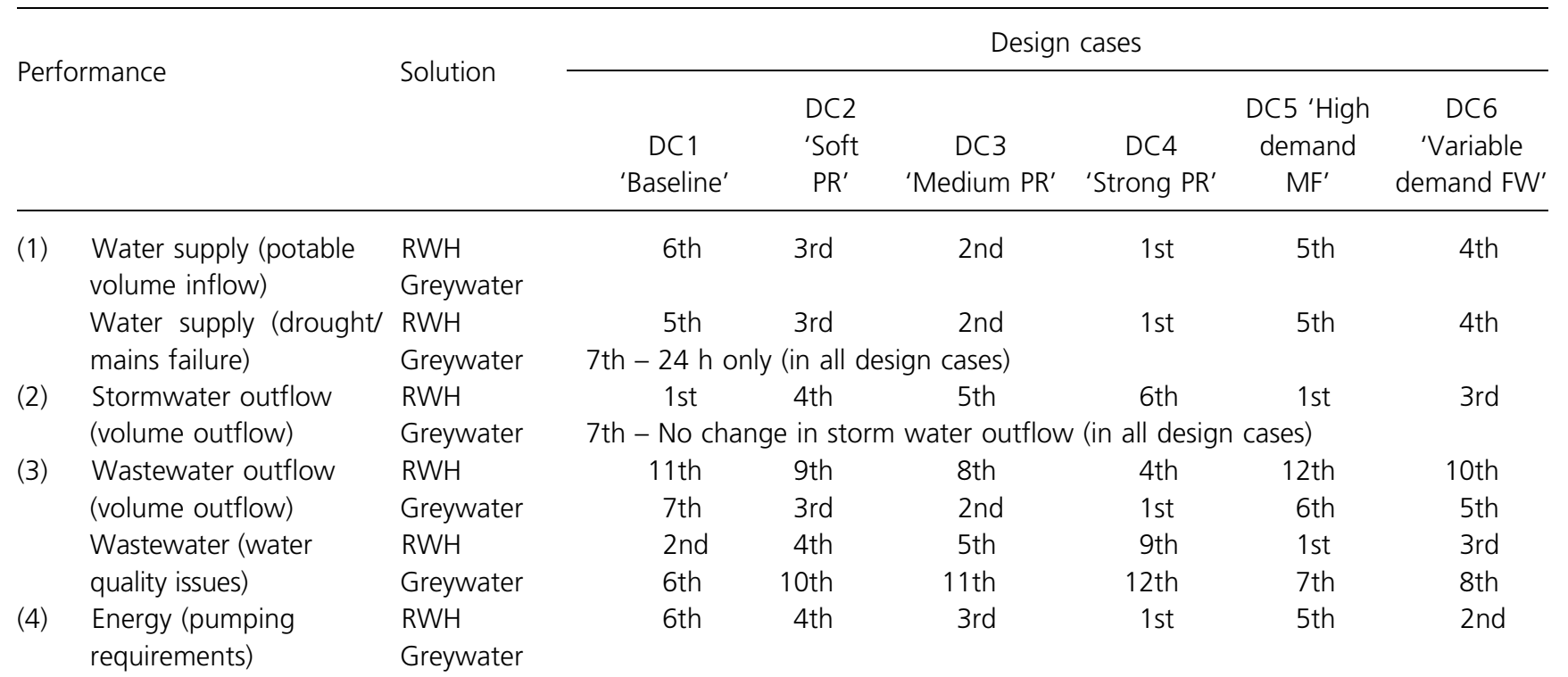

Table 8. Performance of design cases to future challenges 
Engineering Sustainability

Volume 165 Issue ES1
Urban futures and the code for

sustainable homes

Hunt, Lombardi, Farmani, et al. period of time (i.e. 8871 divided by $24.41 /$ day $=40$ days at any time during the year), whereas DC1 and DC6 would meet these demands for the shortest times (i.e. 19641 divided by $53.81 /$ day $=36$ days when the tank is full in winter to 0 days in summer when the tank is empty). This highlights a direct trade-off between achieving improved resilience to drought/ mains failure compared with resilience to pluvial-related flash flood events (see Section 4.2). When considering greywater systems, as long as the mains is connected greywater will continue to be produced (i.e. it is not dependent on localised rainfall within Luneside East. However, for storage without treatment it is assumed a maximum storage of $24-48 \mathrm{~h}$ is allowed (Rozos et al., 2010), no matter which design case is applied.

\subsection{Stormwater outflow (roof related)}

The volumes of outflow are dependent on rainfall, climate, roof area, RWH tank storage and draw off (i.e. it is dependent on Section 4.1). The resilience of the development to high intensity rainfall events is not impacted upon by greywater recycling; however, it may be improved significantly through the implementation of intermediate storage associated with RWH systems. However, the success of such a system depends on how much free capacity there is within the tanks - this is dependent on the daily volume of water being drawn off and the rate at which the $\operatorname{tank}(\mathrm{s}) \operatorname{refill}$. Therefore, if 'volume of stored water as a percentage of RWH tank capacity' is used as a measure of performance it is now the design case with the lowest percentage that would provide most resilience to flash flood events - that is, it is DC1 and DC5 $(0 \%$ at certain times during the year) that have the emptiest $\operatorname{tank}(\mathrm{s})$ and therefore provide the most resilience to a single high intensity rainfall event. Likewise, the least resilient design case is when the least amount of water is drawn off - that is, DC4 (100\% all year). The RWH system is likely to have little impact on improving the resilience to 'fluvial' flood risk in the direct locality as this has been improved greatly through the integration of a 1 in
500 year flood defence. However, it could improve significantly the risk of 'pluvial' flash flood protection within the development.

\subsection{Wastewater outflow}

The volumes are dependent on whether greywater is being recycled and how much is being drawn off (i.e. it is dependent on Section 4.1). RWH in this case will not impact on wastewater outflow volumes. Any improvement in technological efficiency in each design case will lead to reduced wastewater outflows, which need to be processed and cleaned. If reduced volumes are used as a measure of resilience it can be seen that the least resilience is offered in DC5 (with greywater) and the most in DC4 (with RWH). However, if water quality issues are considered a very different picture emerges; lower dilution rates will lead to higher concentrations of urine and faecal matter and thus poorer water quality within the wastewater network, requiring more energy and chemicals to treat. In this case the least dilution occurs in DC4 (with greywater) and the most dilution occurs in DC5 (with RWH). Greywater (without treatment) will carry high levels of biochemical oxygen demand, organic compounds and pathogens and much higher than RWH, therefore the diluting effect from each will be very different. In face of such complexity perhaps Luneside East should be providing infrastructure that is sufficiently flexible (i.e. parts of the network can be isolated in order to run completely independently) in order to allow for radically different forms of local sanitation in the next 25-50 years - for example, composting toilets and local water treatment by means of reed beds.

\subsection{Energy requirements}

Energy requirements are dependent on the volumes of greywater or rainwater being moved around site (therefore linked to Sections 4.1, 4.2 and 4.3 above). When considering the following energy requirements for RWH and greywater systems (EA, 2010): $0 \cdot 5 \mathrm{kWh} / \mathrm{m}^{3}$ (mains), $0 \cdot 6-5 \mathrm{kWh} / \mathrm{m}^{3}$

\section{Design case}

Domestic and

office

DC1

$\mathrm{DC2}$

$\mathrm{DC} 3$

DC4

DC5

DC6
Potable $\mathrm{a}^{\mathrm{a}}$ and non-potable

with no on-site treatment (kWh/day)
Potable $^{a}$ and non-potable with on-site UV treatment (kWh/day)

\footnotetext{
${ }^{\text {a }}$ Assumes that mains potable water has been treated offsite in a water treatment plant.
} 
Engineering Sustainability

Volume 165 Issue ES1
Urban futures and the code for

sustainable homes

Hunt, Lombardi, Farmani, et al. (pumping, no treatment) and $7 \cdot 1 \mathrm{kWh} / \mathrm{m}^{3}$ (pumping with ultraviolet treatment) it can be seen from Table 9 that energy demands will be least in DC4 $(31 \mathrm{kWh} /$ day $)$ when potable supplies only are adopted and highest in DC5 (458 kWh/day) when non-potable water is used and treated. Ward et al. (2010) recognise that $4 \%$ of the energy required to pump non-potable water may be for pumping, the rest is lost due to pump inefficiencies and standby mode. Notwithstanding these losses, the demand in domestic homes is approximately $1 \%$ of total yearly demands (assuming $4500 \mathrm{kWh} /$ year) and this is not dissimilar to the value of $0.07 \%$ reported by Ward et al. (2011) for offices.

The analysis presented here shows how technological changes can be made and how elements of resilience can begin to be tested when considering a broad range change of water demands (i.e. $-54 \%$ to $+30 \%$ compared with the baseline case DC1). This analysis has shown that a solution should not be considered technically resilient just because it performs best when using a single measure. The interdependencies within an infrastructure network mean that ripple effects and compromised performance could be felt elsewhere. In addition, a greater appreciation of technical resilience will require cognisance of changes to user behaviour (Section 5.1), outdoor demands (Section 5.2) and climate change (Section 5.3). Moreover, it would require impacts within the wider Lancaster geography beyond the Luneside East 'pixel' to be examined. For example, how might the resilience of the whole network system be affected by changes made in Luneside East, and how might this benefit (or not) the wish for the wider Lancaster area to become less unsustainable - that is, act locally but think globally? The answer is not straightforward and certainly would require rigorous analysis of the complete network (potable, non-potable, wastewater and stormwater systems) in order to make an assessment of residual holding times and related water quality issues therein. Further complexities will arise when cross-connecting households and offices (proposed here) while operating part of the network at a localised level and part at regional scale where control of water flows, water treatment and water quality are important issues. Moreover, a loss of redundancy associated with high efficiency (and new) operations could lead to reduced reliability when connecting into a larger, older network (Nelson and Sterling, 2012). Whatever the decisions finally taken in Luneside East this paper has highlighted that engineering resilience is a very complex issue and would require very sophisticated forms of analysis in order to ensure that the design of interrelations between people, infrastructure and resources is sustainable in the face of surprises and the unexpected (Holling, 1996). Notwithstanding this finding, judging its ecological, environmental, economic, community and social governance and engineering resilience would be no trivial task, even at a local scale
(Rogers et al., Resistance and resilience - paradigms for critical local infrastructure, in preparation). Complex system management, multidisciplinary approaches in addition to sustainable planning, design, operation and maintenance of these systems will be required (Nelson and Sterling, 2012). However, while complexity should never be over-simplified it is apparent that it is necessary to find ways of simplifying it enough (Einstein's philosophy) in order to increase engagement across all sectors.

\section{Discussion}

Many of the discussion points included in this section follow on from the workshop with LCC in which the limitations of the previous analyses (and UK policy) were considered.

\subsection{Water-using behaviour}

Within this paper it has been possible to analyse rigorously the effects of making changes to one variable (technological efficiency) while keeping user behaviour (and climate change) fixed. This allowed rigorous analysis to identify the impact of the former while setting a baseline for future analysis of the latter.

In order to consider sustainability properly in the longer term (i.e. once occupants move into the development) the impact of user behaviour cannot be ignored. Unfortunately, when current UK policy is interrogated more fully we find that reward is given only for the adoption of more efficient waterusing technologies (as considered here) rather than the actual metered volume of water being used. In other words, there appears to be much in policy to incentivise people to construct and purchase $\mathrm{CSH}$ level 6 homes; however, there is little to deter occupants from far exceeding the behavioural assumptions made for them. For example, as long as a water-efficient dishwasher is adopted it can be run a quarter full or as long as a low-flow shower head is adopted it can be used as frequently or as long as desired. In other words, the inclusion of user behaviour on water demands (and therefore infrastructure requirements) can be equally as influential as technological efficiency (Figure 2). For example, if the occupants in Luneside East took $7 \cdot 15$-min showers ( $8 \mathrm{l} / \mathrm{min}$ flow rate) 1.43 times a day (UK data from Table 3) this would increase water demands and wastewater outflow by $47 \mathrm{l}$ /person per day compared with the base case DC1, and if the occupants took 8.7-min showers 1.97 times a day (USA data from Table 3) this would increase water demands and wastewater outflow by 102 1/person per day. In other words, technologically efficient appliances have been adopted; however, demands have increased above the base case (area above diagonal line in Figure 2). Allied to this would be the case in which a watersaving technology does not perform as assumed. For example, an occupant may adopt a low-flush or dual-flush WC (2.6 1 and 4.51 ) and end up flushing twice (or replacing it with a 
Engineering Sustainability

Volume 165 Issue ES1
Urban futures and the code for

sustainable homes

Hunt, Lombardi, Farmani, et al. higher consumption model) to clear the waste away. Flushing once on each setting for a dual-flush toilet would lead to a total flush of 7.11 - an increase rather than a decrease in water consumption as compared with a standard 6.01 flush. Whereas legislation would need to ensure that highly efficient technologies are adopted and not replaced with highly inefficient technologies (i.e. a low-flow shower replaced by a power shower), perhaps through technology preservation orders or similar policy incentives, these need to be accompanied by radical steps to incentivise sustainable behaviour. Education is always key and requires a variety of approaches - for example, information boards/plaques, building user manuals, community group information packs and local community collective actions. Certainly it can be seen that self-monitoring (with and without smart meters) facilitates long-term reductions in water demand in sustainable communities such as Bedzed (UK), Hammersby Sjöstad (Stockholm), Frieberg (Germany) and water-scarce countries such as Australia (Graymore et al., 2010). (The RWH plant in Bedzed was decommissioned shortly after opening and thus a reduction in water demands came about only through the adoption of water-efficient appliances and a step change in user behaviour (Shirley-Smith and Butler, 2008). Allied to this, sustainable user behaviour can be facilitated by the adoption of 'smart' technologies - for example, showers that bleep after each minute of use (McDonald et al., 2011). For those less willing to change by this route perhaps legislation could help by introducing a progressive water levy as in Hong Kong (Yue and Tang, 2011). Such a system in the UK could be billed through existing water meters and might allow for the first $50 \mathrm{l} /$ person per day (in line with the minimum required amount of water to live) to be provided at the lowest rate, or even be provided for free for those on low incomes. The next tariff (tariff 2) would then be charged between $50 \mathrm{l} /$ person per day up to $80 \mathrm{l} /$ person per day (i.e. CSH level 6); tariff 3 would operate between $801 /$ person per day and 105 1/person per day (CSH level 4); tariff 4 would operate between 105 1/person per day and 120 1/person per day (CSH level 1); the highest tariff (tariff 5) would operate above 1201.

\subsection{Outdoor water use}

Throughout this paper consideration of external water uses (e.g. water for gardening, car washing and water features) has not been included. This is because the $\mathrm{CSH}$ policy requirement (upon which the $\mathrm{CSH}$ calculator is based) does not consider external water use. This is unfortunate because these water demands can be met to some extent through greywater or RWH systems, although for greywater there can be health implications (Eriksson et al., 2002). Part $\mathrm{G}$ of the building regulations (in particular, regulation $17 \mathrm{~K}$, implemented in April 2010) does include a nominal 5 1/person for outdoor use on top of the levels stipulated for CSH level 1 (HM Government, 2010). However, this does not consider the role of greywater or RWH in meeting these demands. Moreover the value adopted might be considered conservative and unfortunately does not reflect how the demand is broken down or how it can be changed. For example, garden watering is dependent on season, garden size, flower/ shrub type and stage of growth, density of planting (Roebuck, 2007) and the technologies used to water them - for example, an unregulated sprinkler system versus drip irrigation versus a watering can. Likewise, water used for car washing is related to car ownership and the many options for washing cars - for example, a drive-in washer system versus a home jet wash system versus a bucket of water and a sponge (Randolph and Troy, 2008).

While allotments have not been encouraged for this development, there is potential for residents to adopt grow bags and window boxes - all of which require water and all of which could be supplied through greywater or RWH. In addition, on site there will be many types of trees that have substantial needs for sustained irrigation, as do some types of green wall. In addition, the potential to store water within a green roof as opposed to an underground tank cannot be ignored. However, this should be considered against the requirements for slower release of water and the implications for water quality, not least if the water is to be re-used as a non-potable source on site (Shirley-Smith et al., 2008).

Perhaps more social pressure or UK legislation/regulation is required in order to minimise external water use and ensure that it is supplied only through non-potable sources. This exists currently in other European and non-European countries - for example, Germany (Nolde, 2005, 2007) and Australia (Brennan and Patterson, 2004).

\subsection{Climate change}

In general it is assumed that RWH systems are adopted as possible 'sustainability' solutions to enable adaptation to the effects of climate change (Pandey et al., 2003). The RWH calculations presented within this paper are based on monthly average rainfalls over a 30 -year period and assume an unchanged climate. First, this allows the impact of one changing variable (technology) to be rigorously analysed, and second, it sets a baseline on which future climate changes can be imposed. The way in which RWH systems operate now may be significantly different if climate changes occur - that is, drier summers $(-20 \%$ mean summer rainfall under a medium emissions scenario with $50 \%$ probability level) and wetter winters $(+30 \%$ mean summer rainfall under a medium emissions scenario with $50 \%$ probability level) for the Luneside East region (IPCC, 2000, 2008; UKCIP, 2011) and probably more frequent peak storm events (Butler and Davies, 2011). Figure 10 shows the impact of such changes on RWH tank storage volumes (less stored water in summer and more in winter) and stormwater outflow (lower outflows in summer and higher outflows in winter) - DC2 encounters 2.5 months without sufficient water, compared with 0 months under 
Urban futures and the code for

sustainable homes

Hunt, Lombardi, Farmani, et al.

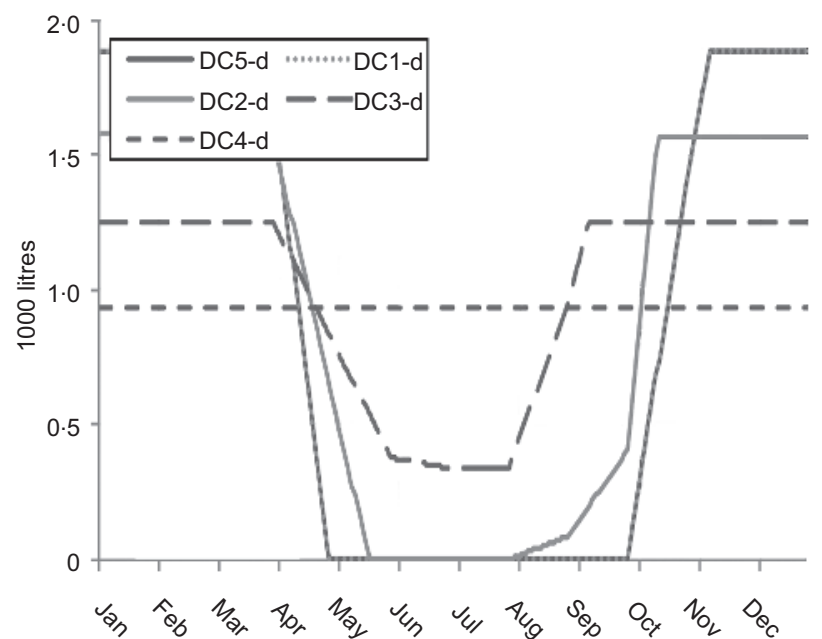

(a)

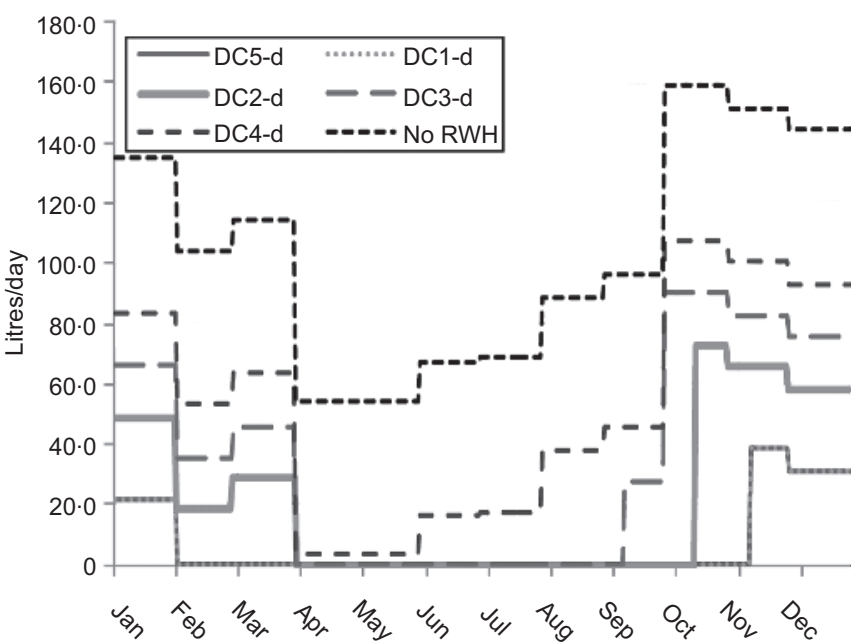

(b)

Figure 10. Effect of climate change (medium variant) on RWH system (40 $\mathrm{m}^{2}$ pitched roof): (a) RWH tank volumes; (b) stormwater outflow

normal climatic conditions. While there may be a link between user behaviour and climate change (e.g. more frequent showering) these are beyond the scope of this paper.

\subsection{Generic recommendations and other innovative ideas for the site}

The preference would be to adopt a resilient 'sustainability solution' that can withstand change and deliver the intended benefits no matter how the future develops. An equally sensible alternative is to adopt a solution knowing that it has vulnerabilities while making due preparations to implement changes so that benefits continue to be achieved during the lifetime of the development. The worst possible undertaking would be to adopt a solution that is doomed to future failure without knowing it. Based on the analysis conducted here some generic recommendations for RWH and greywater solutions are given below.

Be aware that reductions in non-potable demands will result in increased surplus for supply, therefore when considering adopting an RWH solution trade-offs between stored volume for supply and spare capacity for flood protection need to be managed.

- Avoid compromising roof space for RWH collection.

- Avoid using RWH in high occupancy dwellings and perhaps consider alternative solutions to RWH where occupancy rates are high compared with available roof space.

- Be aware that occupancy rates do not affect greywater availability per person; however, be aware that the performance of a greywater system relies on the potable mains water supplies to produce greywater. Moreover, greywater cannot be stored for more than $24 \mathrm{~h}$ without treatment.

Be aware that in some cases payback periods for RWH and greywater solutions are already prohibitively long and decreasing non-potable demands will increase these further.

- Be aware that greywater is not a robust solution in cases in which greywater supplies reduce and non-potable demands remain constant, or worse still increase, therefore avoid adopting water-efficient showers, baths and sinks in the absence of water-efficient WC.

Several other innovative ideas for the site were discussed at the workshop and they are presented, although not critically discussed. The area between the two intersecting embankments, in the base of the ' $\mathrm{V}$ ' shape associated with the dismantled railway track (Figure 1) could be covered over (becoming underground space) creating a new elevated ground surface level. This would allow for a barrier to be created over lands that were previously contaminated. In addition, it would facilitate ease of placement for newly required underground infrastructure services; to include, for example, new pipes (gas and water), cables (high voltage, low voltage and communications), RWH tanks, ground source heat pumps, etc. If this was introduced in conjunction with a higher degree of impermeable surfaces on site (say $80 \%$ ) and larger volume RWH tanks this could reduce the risk of contaminants being flushed, both now and in the future. Alternatively, the location of the gas storage holder could be 
Engineering Sustainability

Volume 165 Issue ES1
Urban futures and the code for

sustainable homes

Hunt, Lombardi, Farmani, et al. used as an intermediate storage location for rainwater captured on site, although the cost for casting this in situ would need to be factored in, as would the cost of pumping.

\section{Conclusions}

This paper has shown that changes to technological efficiency in addition to the adoption of either greywater recycling or RWH systems offer very different benefits when considering impacts and requirements for underground space and provision of water infrastructure in Luneside East, as listed below.

- In a future in which changes to water efficiency alone are considered (i.e. no change in behaviour) the demand for mains water supply (and therefore the capacity requirement for related mains water infrastructure) could be reduced by a maximum of approximately $50 \%$ when compared with the baseline in DC1.

- In a future in which water efficiency measures are high and alternative supplies of water (i.e. either greywater or RWH) are used to meet non-potable demands (e.g. DC4) mains water infrastructure capacity could be reduced by $75 \%$ when compared with the baseline in DC1.

- The lowest wastewater outflow can be achieved in a future in which non-potable demands are low and all greywater (i.e. domestic and offices) is recycled - for example, DC4. This requires $25 \%$ of the wastewater infrastructure capacity compared with the baseline in DC1. However, greywater recycling has the biggest impact in terms of reducing wastewater outflow in a future in which non-potable demands are high - for example, DC5. In this case total outflows were reduced by $62 \%$ from $180.7 \mathrm{~m}^{3} /$ day (no greywater recycled) to $67 \cdot 8 \mathrm{~m}^{3} /$ day (domestic and office greywater recycled).

- RWH will have the most impact on reducing rainwater outflow (from roof tops) to a stormwater system in a future in which non-potable demands are high - for example, DC1 and DC5. However, the collection areas (66\% site) and tank sizes (e.g. 1964 1/domestic property) will be biggest. The least impact on outflow will be in a future in which nonpotable demands are low (DC4) and these will require smaller collection areas ( $24 \%$ site) and tanks (e.g. 887 1/ domestic property).

- There is a trade-off to be made in the future between providing sufficient empty storage capacity in RWH tanks to provide pluvial flood protection and sufficient stored rainwater for supplying non-potable year-round needs. Climate change will reduce RWH supplies in summer months and increase RWH supplies in winter months.

- When considering installing small-scale greywater or RWH systems in Luneside East the payback period will be longest and energy demands lowest in a future in which nonpotable demands are low (e.g. DC4). Payback will be shortest and energy demands highest in a future in which non-potable demands are high (e.g. DC5).

Does this take us far enough? The answer is no, not least because it is not possible to be certain about what scenario (or combination of scenarios) might come to pass in Luneside East. However, it is unquestionable that a better understanding of the problems, through the adoption of the UF methodology, has been achieved. While it might be suggested that a combined system would result in dual benefits there is little merit in adopting this, not least in terms of water quality and economics. Therefore, the way in which respective benefits and trade-offs might be managed to best effect in terms of sustainability and resilience needs careful consideration. Substantial evidence has been provided to suggest that tools need to be developed in order to allow users (e.g. planners, developers) to have a better understanding of engineering interdependencies, while being able simultaneously to assess sustainability and resilience impacts, when making changes to such things as technologies, user behaviour, climate and building type(s). Reassuringly, these are being developed as part of UF research and will facilitate future decision making in this respect.

\section{Acknowledgement}

The authors wish to thank the Engineering and Physical Sciences Research Council for their support during this second round of sustainable urban environments (SUE2) funding under grant number EP/F007426/1.

\section{REFERENCES}

Boyko CT, Gaterell MR, Barber ARG et al. (2012) Benchmarking sustainability in cities: The role of indicators and future scenarios. Global Environmental Change 22(1): 245-254.

Brennan MJ and Patterson RA (2004) Economic analysis of greywater recycling. Proceedings of 1st International Conference on Onsite Wastewater Treatment and Recycling, Perth, 11-13 February 2004. Environmental Technology Centre, Murdoch University, Perth, Australia.

Bruneau M, Chang SE, Eguchi RT et al. (2003) A framework to quantitatively assess and enhance the seismic resiliency of communities. Earthquake Spectra 19(4): 733-751.

BSI (2009) BS 8515: Rainwater harvesting systems - code of practice. BSI, London, UK.

Building (Approved Inspector, etc.) Regulations (2000) (as amended)

Building Regulations (2000) (as amended)

Butler D and Davies JW (2011) Urban Drainage, 3rd edn. Spon Press, London, UK.

Butler D, May R and Ackers J (2003) Self-cleansing sewer design based on sediment transport principles. Journal of Hydraulic Engineering 129(4): 276-282.

Butler D, Memon FA, Makropoulos C, Southall A and Clarke L 
Engineering Sustainability

Volume 165 Issue ES1
Urban futures and the code for

sustainable homes

Hunt, Lombardi, Farmani, et al.
(2010) WaND - Guidance on Water Cycle Management for New Developments C690. CIRIA, London, UK.

Chambers VK, Creasey JD, Glennie EB, Kowalski M and Marshallsay D (2005) Increasing the Value of Domestic Water use Data for Demand Management. WRC, Swindon, Wiltshire, UK, WRC, collaborative project CP187, report no. p6805.

Chenoweth J (2007) Minimum water requirement for social and economic development. Desalination 229(3): 245-256.

CLG (Department of Communities and Local Government) (2010a) Code for Sustainable Homes: Technical Guide. HMSO, London, UK.

CLG (2010b) Water Efficiency Calculator for New Dwellings: The Government's Calculation Methodology for Assessing Water Efficiency in New Dwellings. HMSO, London, UK.

Defra (Department for Environment, Food and Rural Affairs) (2010) Green Government: Guidance on New Targets Water. See http://archive.defra.gov.uk/sustainable/ government/gov/estates/targets-guidance.htm (accessed 27/ 01/2012).

DeOreo WB, Mayer PW, Martien L, et al. (2011) California Single-Family Water Use Efficiency study. Aquacraft Water Engineering and Management, Boulder, Colorado, USA.

Dimitrov G (2004) The economic efficiency of water saving toilets in Bulgaria. Proceedings of the 9th BAWK Scientific and Practical Conference. Bulgarian Association for Water Supply and Sewerage, Borgas, Bulgaria.

Dixon A, Butler D and Fewkes A (1999a) Guidelines for greywater reuse - health issues. CIWEM Water and Environmental Management Journal 13(5): 322-326.

Dixon A, Butler D and Fewkes A (1999b) Water saving potential of domestic water re-use systems using grey water and rainwater in combination. Water Science and Technology 39(5): $25-32$.

Dziegielewski B, Kiefer JC, Opitz EM, Porter GA and Lantz GL (2000) Commercial and Institutional End Uses of Water. AWWA Research Foundation.

EA (Environment Agency) (2007) Conserving Water in Buildings. A Practical Guide. Environment Agency, Bristol, UK.

EA (2009) International Comparisons of domestic per capita consumption. A report prepared for the Environment Agency by Aquaterra.

EA (2010) Energy and carbon implications of rainwater harvesting and greywater recycling. Report: SC090018 for the Environment Agency.

EC (European Commission) (2009a) Study on Water Efficiency Standards. European Commission (DG ENV). See http:// ec.europa.eu/environment/water/quantity/pdf/ Water\%20efficiency\%20standards_Study2009.pdf (accessed 19/12/2011).

EC (2009b) Study on Water Performance of Buildings. European Commission (DG ENV). See http://ec.europa. eu/environment/water/quantity/pdf/Water
\%20Performance $\% 20$ of $\% 20$ Buildings_Study2009.pdf (accessed 19/12/2011).

Electris C, Raskin P, Rosen R and Stultz J (2009) The Century Ahead: Four Global Scenarios. Tellus Institute, Technical Documentation.

Eriksson E, Auffarth K, Henze M and Ledin A (2002) Characteristics of grey wastewater. Urban Water 4(1): 85104.

Farmani R, Butler D, Hunt DVL, et al. (2012) Scenario-based sustainable water management and urban regeneration. Proceedings of the Institution of Civil Engineers Engineering Sustainability 165(1): 89-98.

Fewkes A and Butler D (2000) Simulating the performance of rainwater collection and reuse systems using behavioural models. Building Services Engineering Research and Technology 21(2): 99-106.

Gascon L, Arregui F, Cobacho R and Cabrera E (2004) Urban water demands in Spanish cities by measuring end - use consumption patterns. 2004 water sources conference, Austin, Texas.

Grant N (2008) A Critique of the CSH Water Efficiency Requirements. Good homes Alliance.

Graymore M, Wallis A and O'Toole K (2010) Rural and regional water use behaviour change: A matter of personal contact and diaries. Proceedings of the 11th Biennial Conference of the International Society for Ecological Economics, Advancing Sustainability in a Time of Crisis, Oldenburg, Germany.

Hatt BE, Deletic A and Fletcher TD (2006) Integrated treatment and recycling of stormwater: a review of Australian practice. Journal of Environmental Management 79(1): 102 113.

HM Government (2010) Sanitation, Hot Water and Water Efficiency - Part G. Building Regulations. NBS part of RIBA, London, UK, Building Regulations 2010.

Holling CS (1996) Engineering resilience versus ecological resilience. In Engineering Within Ecological Constraints (Schulze P (ed.)). National Academy Press, Washington, DC, USA.

Hunt DVL, Farmani R, Lombardi DR, Butler D and Memon FA (2010a) A sustainability toolkit for scenario based urban futures research into water provision: Part 1 Methodology. Sustainable water management in developing countries - challenges and opportunities. Proceedings of the UNESCO-DelPHE International Conference on Sustainable Water Management (SWM2010), Jamshoro, Pakistan, 15-17 September 2010, ISBN 0-9539140-4-6, pp. 355-366.

Hunt DVL, Farmani R, Lombardi DR, Butler D and Memon FA (2010b) A sustainability toolkit for scenario based urban futures research into water provision: Part 2 - Toolkit. Sustainable water management in developing countries challenges and opportunities. Proceedings of the UNESCO- 
Engineering Sustainability

Volume 165 Issue ES1
Urban futures and the code for

sustainable homes

Hunt, Lombardi, Farmani, et al.
DelPHE International Conference on Sustainable Water Management (SWM2010), Jamshoro, Pakistan, 15-17 September 2010, ISBN 0-9539140-4-6, pp. 366-377. Hunt DVL, Jefferson I and Rogers CDF (2011) Assessing the sustainability of underground space usage - a toolkit for testing possible urban futures. Journal of Mountain Science 8(2): 211-222.

IPCC (Intergovernmental Panel on Climate Change) (2000) Emissions scenarios: summary for policy makers. In Special Report on Emissions Scenarios (Nakicenovic N (ed.)). Clbridge University Press, Cambridge, UK.

IPCC (2008) Climate change and water: technical paper of the intergovernmental panel on climate change (Bates BC, Kundzewicz ZW, Wu S and Palutikof JP (eds)). IPCC secretariat, Geneva, Switzerland.

Jeppeson B (1996) Domestic greywater re-use: Australia's challenge for the future. Desalination 106(1-3): 311315.

Jones A, Nesaratnam S and Porteous A (2008) The Open University Household Waste Study: Key Findings from 2008. Prepared for Defra.

Lancaster University (2010) Environmental Science Research. Meteorological Office Climatological Station No. 7236. See http://www.es.lancs.ac.uk/hazelrigg/ (accessed 19/12/ 2011).

LCC (Lancaster City Council) (2004) LE Development Brief (Revised). Lancaster District Local Plan, Supplementary Planning Guidance Note 4. LCC, Lancaster, UK.

LCC (2007a) Sustainable Appraisal: Core Strategy Submission Document. LCC, Lancaster, UK.

LCC (2007b) Sustainable Appraisal: Core Strategy Submission Version: Appendices. LCC, Lancaster, UK.

Leggett DJ, Brown R, Brewer D, Stanfield G and Holliday E (2001a) Rainwater and Greywater Use in Buildings. Best Practice Guidance C539. (ISBN: 978-0-86017-539-1). CIRIA, London, UK.

Leggett DJ, Brown R, Stanfield G and Holliday E (2001b) Rainwater and Greywater Use in Buildings. Decision-making for Water Conservation PR80. (ISBN: 978-0-86017-880-4). CIRIA, London, UK.

McDonald A, Butler D and Ridgewell C (2011) Water demand: estimation, forecasting and management. In Water Distribution Systems (Savic DA and Banyard JK (eds)). ICE Publishing, London, UK, Ch. 3.

Makropoulos CK, Natsis K, Liu S, Mittas K and Butler D (2008) Decision support for sustainable option selection in integrated urban water management. Environmental Modelling and Software 23(12): 1448-1460.

Mayer PW, DeOreo WB, Opitz EM, et al. (1999) Residential End Uses of Water. AWWA Research Foundation.

Memon FA, Butler D, Han W, et al. (2005) Economic assessment tool for greywater recycling systems. Proceedings of the
Institution of Civil Engineers - Engineering Sustainability 158(3): 155-161.

Mitchell VG (2007) How important is the selection of computational analysis method to the accuracy of rainwater tank behaviour modelling? Journal of Hydrological Processes 21(21): 2850-2861.

MTP (Market Transformation Programme) (2008) Bath Design and Efficiency - BNWAT07. Briefing note relating to policy scenario objectives in policy brief. MTP.

Mustow S and Grey R (1997) Greywater and Rainwater Systems: Recommended UK Requirements, BSRIA Ltd, Bracknell, UK, Report 13034/2.

Nelson PP and Sterling RL (2012) Sustainability and resilience of underground urban infrastructure: new approaches to metrics and formalism. Proceedings of Geocongress 2012, San Francisco. ASCE, Reston, VA, USA.

Nolde E (2005) Greywater recycling systems in Germany results, experiences and guidelines. Water Science and Technology 51(10): 203-210.

Nolde E (2007) Possibilities of rainwater utilisation in densely populated areas including precipitation runoffs from traffic surfaces. Desalination 215(1): 1-11.

Pacific Institute (2003) Waste Not, Want Not. The Potential for Urban Water Conservation in California. Pacific Institute, Oakland, California, USA.

Pandey DN, Gupta AK and Anderson DM (2003) Rainwater harvesting as an adaptation to climate change. Current Science 85(1): 46-59.

Randolph B and Troy P (2008) Attitudes to conservation and water consumption. Environmental Science and Policy 11(5): $441-455$.

Ratcliffe J (2001) Imagineering global real estate: a property foresight exercise. Foresight 3(5): 453-475.

Roebuck RM (2007) $A$ Whole Life Costing Approach for Rainwater Harvesting Systems. PhD thesis, University of Bradford, Bradford, UK.

Rogers CDF, Lombardi DR, Leach JM and Cooper RFD (2012) The urban futures methodology applied to urban regeneration. Proceedings of the Institution of Civil Engineers Engineering Sustainability 165(1): 5-20.

Rozos E, Makropoulos C and Butler D (2010) Design robustness of local water-recycling schemes. ASCE Journal of Water Resources Planning and Management 136(5): 531-538.

Shirley-Smith C and Butler D (2008) Water management at Bedzed - some lessons. Proceedings of the Institution of Civil Engineers - Engineering Sustainability 161(2): 113122.

Shirley-Smith C, Cheeseman C and Butler D (2008) Sustainability of water management in Zaragoza City. Water and Environment Journal 22: 287-296.

Tal T, Sathasivan A and Bal Krishna KC (2011) Effect of different disinfectants on grey water quality during storage. Journal of Water Sustainability 1(1): 127-137. 
Urban futures and the code for

sustainable homes

Hunt, Lombardi, Farmani, et al.
The National Archives (1999) Water Supply (Water Fittings) Regulations. No. 1148. See http://www.legislation.gov.uk/ uksi/1999/1148/contents/made (accessed 19/12/2011).

UKCIP (2011) UKCP09. Maps of Future Climate for North West England. See http://www.ukcip.org.uk/uk-impacts/northwest/maps/ (accessed 19/12/2011).

UN (2003) Water for People Water for Life. Executive Summary. UN, United Nations World Water Development report.

Viera P and Almeida M (2007) Household water use: a Portuguese field study. Proceedings of the 4th IWA Specialist Conference on Efficient Use of Urban Water.

Waggett R and Arotsky C (2006) Key performance Indicators for Water Use in Offices W11. CIRIA, London, UK.

Ward S, Memon FA and Butler D (2010) Rainwater harvesting: model-based design evaluation. Water Science and Technology 61(1): 85-96.

Ward S, Butler D and Memon FA (2011) Benchmarking energy consumption and $\mathrm{CO}_{2}$ emissions from rainwater-harvesting systems: an improved method by proxy. Water and Environment Journal doi: 10.1111/j.1747-6593.2011. 00279.x.
Waterwise (2007a) Choosing a Washing Machine. See http:// www.waterwise.org.uk/reducing_water_wastage_in_the_ uk/house_and_garden/choosing_a_washing_machine. htMl.

Waterwise (2007b) Choosing a Dishwasher. See http://www. waterwise.org.uk/reducing_water_wastage_in_the_uk/ house_and_garden/choosing_a_dishwasher.htMl.

Wilson S, Bray R and Cooper P (2004) Sustainable Drainage Systems: Hydraulic, Structural and Water Quality Advice C609B (ISBN: 978-0-86017-609-1). CIRIA, London, $\mathrm{UK}$.

Woods-Ballard B (2007) The SUDS Manual C697 (ISBN: 978-086017-697-8). CIRIA, London, UK.

Yue DPT and Tang SL (2011) Sustainable strategies on water supply management in Hong Kong. Water and Environment Journal 25(2): 192-199.

Zadeh SM, Lombardi DR, Hunt DVL and Rogers CDF (2010) Local area greywater symbiosis approach to a more sustainable urban water management. The Sustainable World, Ecology and the Environment 142: 11 (see also IWA World Water Congress, Montreal, 19-23 September 2010).

\section{WHAT DO YOU THINK?}

To discuss this paper, please email up to 500 words to the editor at journals@ice.org.uk. Your contribution will be forwarded to the author(s) for a reply and, if considered appropriate by the editorial panel, will be published as discussion in a future issue of the journal.

Proceedings journals rely entirely on contributions sent in by civil engineering professionals, academics and students. Papers should be 2000-5000 words long (briefing papers should be 1000-2000 words long), with adequate illustrations and references. You can submit your paper online via www.icevirtuallibrary.com/content/journals, where you will also find detailed author guidelines. 